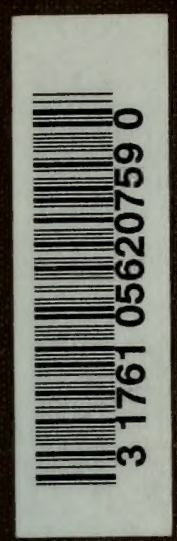

QK

629

.P7M76

ESCI 





\section{AMERICAN BOLETES}

BY

WILliam ALPHONSO MURRILl, A.M., Ph.D.

ASSISTANT DIRECTOR OF THE NEW YORK BOTANICAL GARDEN

ASSOCIATE EDITOR OF NORTH AMERICAN FLORA

EDITOR OF MYCOLOGIA

NEW YORK

PUBLISHED BY THE AUTHOR

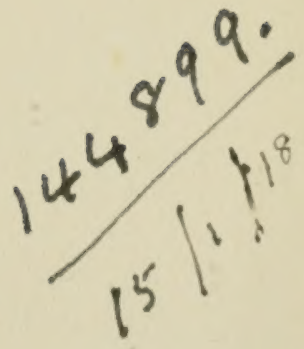


Copyright, I9I 4

By William Alphonso Murrill LANCASTER, PA. 


\section{PREFACE}

Boletes are tube-bearing fungi differing from the polypores chiefly in their fleshy consistency and terrestrial habit, usually occurring on the ground in woods during late summer and autumn. The species are difficult to distinguish, even in the fresh state, and when the large amount of water they contain is eliminated the dried specimens bear little resemblance to the originals. The accompanying blank has been found convenient for field notes.

Many of the best edible fungi in temperate regions belong to this group, and the dangers of being poisoned are relatively small. Species with bitter or otherwise objectionable taste should be avoided, and especially all plants having red or reddish tube-mouths. The sensitive bolete, which promptly turns blue when touched or broken, has also caused mild poisoning in some cases. Many species have not been thoroughly tested, however; hence it is wise to eat sparingly of all such plants until well known.

New York Botanical Garden,

W. A. Murrill

October I5, I9I4 



\section{BLANK FOR FIELD NOTES}

NAME.

Locality, Date

Habitat

Habit

Size

PILEUS

Shape

Color

Changes

Surface

Margin

Veil

Annulus

CONTEXT.

Consistency

Color

Changes

Odor, taste

TUBES.

Attachment

Color

Changes

Mouths

Form

Spores

Print

STIPE

Attachment

Shape

Color

Changes

Surface

Substance

Changes

Remarks. 
Digitized by the Internet Archive in 2010 with funding from University of Toronto 


\section{AMERICAN BOLETES}

Including species occurring in North America, Central America, the West Indies, and all other islands between North America and South America with the exception of Trinidad. The tropical representatives of the family are extremely limited, both in number and distribution.

\section{BOLETACEAE}

Hymenophore annual, nearly always terrestrial and centrally stipitate; context fleshy; hymenium poroid, fleshy, never gelatinous.

Tubes not arranged in radiating rows (except in one or two species of Boletus).

Spores hyaline, often becoming yellowish; stipe hollow, not reticulate.

I. GYROPORUS.

Spores rosy or flesh-colored; stipe solid, usually reticulate.

Spores ochraceous to brown or black.

2. TYLOPILUS.

Stipe neither glandular-dotted nor annulate.

Mouths of tubes never uniformly red nor reddish-brown, tubes unicolorous.

Mouths of tubes red or reddish-brown, tubes yellowish within.

Stipe either glandular-dotted or annulate.

Stipe glandular-dotted, exannulate.

Stipe annulate, glandular-dotted in some species.

3. Ceriomyces.

4. Suillellus.

5. Rostkovites.

Spores ochraceous to yellowish-brown,

smooth, usually oblong-ellipsoid.

Sporophore not covered with a yellow powder.

Pileus smooth, viscid.

6. Boletus.

Pileus floccose-verrucose, dry.

Sporophore covered with a conspicuous yellow powder.

7. Boletellus.

Spores brownish-black, rough, subglobose.

Tubes arranged in radiating rows.

Stipe exannulate.

Stipe annulate.

8. Pulverobòletus.

9. Strobilomyces.

ro. Boletinellus.

II. Boletinus.

\section{GYROPORUS Quél.}

Hymenophore annual, terrestrial, centrally stipitate; surface dry, minutely tomentose to floccose-squamose; context white, 
less compact than in most members of the family and therefore drying more readily; tubes free, small, cylindric, white, not covered with a veil; spores ellipsoid, smooth, hyaline, at length pale-yellow; stipe soft and spongy within, usually becoming hollow.

Context white, quickly changing to blue when wounded; pileus grayish-yellow, floccose.

r. G. cyanescens.

Context white, unchangeable.

Pileus reddish-brown.

2. G. castaneus.

Pileus pale-yellowish.

3. G. subalbellus.

\section{Gyroporus cyanescens (Bull.) Quél.}

Pileus convex, gregarious at times, $6-\mathrm{I} 2 \mathrm{~cm}$. broad, $\mathrm{I} .5 \mathrm{~cm}$. or more thick; surface pale-tan with grayish-white background or slightly brownish, opaque, appressed-tomentose or tomentosesquamulose; margin entire, concolorous, adorned in young plants with a distinct cortina, which is a part of the general hairy covering; context white or grayish-white, sweet, $\mathrm{I} \mathrm{cm}$. or more thick, quickly changing to indigo-blue when wounded; hymenium nearly plane, depressed near the stipe; tubes free, short, about $4 \mathrm{~mm}$. long, white to yellowish, quickly changing to indigo-blue when wounded, mouths circular, small, edges thin, entire; spores ellipsoid, smooth, hyaline to pale-yellowish, 9-II $\times 5^{-6 \mu}$; stipe ventricose, hollow at maturity, concolorous, clothed with cottony threads, white within, becoming indigo-blue when wounded, 5-10 $\mathrm{cm}$. long, I.5-3.5 cm. thick.

Frequent in woods and groves from Canada to North Carolina and west to Minnesota.

\section{Gyroporus castaneus (Bull.) Quél.}

Pileus convex to subexpanded, slightly depressed, gregarious, 3-7 cm. broad; surface smooth, dry, minutely but densely tomentose, orange-brown, fulvous, or reddish-brown; margin thin, usually paler; context white, firm, nutty in flavor, unchanging when wounded; tubes depressed, sinuate, short, waterywhite becoming light-yellow to dark-cremeous, mouths angular, small, stuffed when young, edges thin, entire; spores ellipsoid, smooth, hyaline to pale-ycllowish, $8-9 \times 4.5-5.5 \mu$; stipe subattenuate above and below, cylindric or somewhat flattened, tomentose, bright-brown, lighter at the apex, brittle, loosely stuffed, with a small cylindric cavity at the center, $4-5 \mathrm{~cm}$. long, 6-10 mm. thick.

Very common in open woods throughout temperate North America. Edible. 


\section{Gyroporus subalbellus Murrill}

Pileus convex, rather thick, scattered, $5 \mathrm{~cm}$. broad; surface dry, smooth, finely tomentose to glabrous, pale-isabelline; margin entire, fertile; context spongy-fleshy, easily drying, whitish, unchanging; tubes nearly free, longer than the thickness of the context, mouths light-yellow, unchanging; spores ovoid, smooth, hyaline under a microscope, $7 \times 4.5 \mu$; stipe ventricose, thick, distorted, smooth, pale-isabelline or nearly white, hollow, $7 \mathrm{~cm}$. long.

Found once on sandy soil in mixed woods at Ocean Springs, Mississippi.

\section{TYLOPILUS P. Karst.}

Hymenophore annual, terrestrial or rarely epixylous, centrally stipitate; surface dry, glabrous or minutely tomentose; context white, fleshy, sometimes bitter; tubes small, angular, white, becoming flesh-colored from the spores, not covered with a veil; spores oblong-ellipsoid, smooth, rosy or flesh-colored, rarely inclining to ferruginous; stipe solid, even or reticulate.

Pileus yellow to brown.

Sporophore large; stipe I cm. or more thick.

Context decidedly bitter.

I. T. felleus.

Context not bitter.

2. $T$. indecisus.

Sporophore usually small; stipe about $5 \mathrm{~mm}$. thick, never reticulate.

3. T. gracilis.

Pileus black or blackish; tubes becoming blackish when wounded. 4. T. alboater.

\section{Tylopilus felleus (Bull.) P. Karst.}

Pileus thick, convex, usually $8-15 \mathrm{~cm}$. broad, sometimes reaching a diameter of over $40 \mathrm{~cm}$.; surface smooth, glabrous, variable in color, usually some shade of tan or chestnut, often pink or purplish when young; margin entire, concolorous; context white, often tinged with pink where wounded, at first firm but soft and yielding in older specimens, decidedly bitter, especially when young, sometimes losing its bitter taste with age; tubes adnate, depressed, I-2 cm. long, slender, white, colored at maturity with the flesh-colored spores, mouths angular, of medium size, edges thin, entire; spores fusiform, smooth, fleshcolored, 8-II $\times 3-4 \mu$; stipe cylindric, enlarged below, glabrous, subconcolorous, usually reticulate above, and sometimes entircly to the base, firm, solid, becoming spongy in large specimens, $5^{-12} \mathrm{~cm}$. long, $1.5-2.5 \mathrm{~cm}$. thick.

Extremely common in woods throughout temperate North America, often reaching a foot or more in diameter. It is very bitter and therefore inedible. 


\section{Tylopilus INDECISUS (Peck) Murrill}

Pileus thick, convex, 6-I $2 \mathrm{~cm}$. broad; surface dry, minutely velvety to glabrous, ochraceous-brown to chestnut, having no violet tint when young; margin entire or undulate; context firm, fleshy, white, unchangeable except in old specimens, which become slightly greenish-yellow near the tubes when wounded, taste mild; tubes adnate, not conspicuously depressed, white or grayish-white, becoming flesh-colored from the mature spores, usually changing to brownish when wounded, $0.5-1.5 \mathrm{~cm}$. long, mouths small, subcircular; spores oblong, smooth, dirty-rosecolored, I2-I5 $\times 4 \mu$; stipe subequal, subconcolorous, usually reticulate above, minutely furfuraceous, especially below, firm, solid, 6-Io $\mathrm{cm}$. long, I-2 cm. thick.

Rather common in thin deciduous woods from New York to North Carolina and west to Missouri.

\section{Tylopilus Gracilis (Peck) P. Henn.}

Pileus convex, $3^{-6} \mathrm{~cm}$. broad, rarely larger; surface dry, slightly viscid in wet weather, subtomentose or squamulose, sometimes rimose or reticulate, dull-tan to reddish-brown; context white, unchanging, taste mild, becoming acid; tubes nearly free, depressed, white, becoming deep-flesh-colored, not changing when wounded, mouths small, circular; spores ellipsoid, smooth, subferruginous, I2-I $5 \times 5^{-6 \mu}$; stipe tapering upward, paler and minutely tomentose or hoary above, concolorous, substriate, and furfuraceous below, solid, fleshy, and white within, 6-10 $\mathrm{cm}$. long, $0.5^{-\mathrm{I} .5} \mathrm{~cm}$. thick.

Frequent in woods from Nova Scotia to Georgia, occurring on the ground or on wood very much decayed.

\section{Tylopilus alboater (Schw.) Murrill}

Pileus convex, solitary or gregarious, 6-10 $\mathrm{cm}$. broad, $2 \mathrm{~cm}$. thick; surface pruinose to tomentose, very dark brown to black; margin rather thick, involute when young; context white, changing to pinkish-gray when wounded, taste nutty; tubes adnate, slightly depressed, pale-gray to flesh-colored, changing slowly to black or reddish-black when wounded, I $\mathrm{cm}$. long, mouths small, irregularly circular; spores oblong-ellipsoid, smooth, pointed at one end, dull-flesh-colored, 10-12 $\times 4^{-6 \mu}$; stipe short, subequal, even, concolorous or a little paler than the pileus, pinkish-gray at the apex, velvety at the base, solid, 5-8 $\mathrm{cm}$. long, I. $5^{-2.5} \mathrm{~cm}$. thick.

Occasional in open deciduous woods from New York to Georgia and west to Missouri. 


\section{CERIOMYCES Batt.}

Hymenophore annual, terrestrial, centrally stipitate; surface dry, rarely viscid, glabrous or variously ornamented; context usually white or yellow, sometimes tinged with certain other colors, very rarely poisonous; tubes free or adnate, small, cylindric, sometimes large and angular near the stipe; spores oblongellipsoid, smooth, ochraceous to yellowish-brown; stipe solid, except in one or two species, even or reticulate, exannulate.

Stipe shaggy and lacerate, with reticulate furrows.

Pileus dry, tomentose or reddish-pilose.

Pileus viscid, glabrous.

I. C. Russellii.

2. C. Betula.

Stipe smooth or reticulate with veins.

Tubes white, not stuffed when young and not turning blue when wounded, colored at maturity with the yellowish-brown spores; pileus glabrous (a few subtomentose species have whitish tubes when young).

Stipe smooth; pileus white, smooth.

Stipe reticulate.

Pileus white, with deep chinks forming areolae. Pileus gray, smooth.

Stipe scabrous; pileus smooth, rarely white.

Stipe conspicuously bright-yellow near the base.

Stipe entirely white or grayish-white.

Tubes flesh-colored; pileus glabrous, floccose, or squamulose.

Pileus glabrous.

Pileus adorned with appressed yellowish flocci.

Pileus adorned with conspicuous dark-purple scales.

Tubes bright-yellow, sometimes tinged with scarlet, unchanging at maturity or in dried specimens.

Stipe smooth; pileus glabrous.

Stipe $2 \mathrm{~cm}$. thick; spores $15 \times 6 \mu$.

Stipe less than $1 \mathrm{~cm}$. thick; spores ro $\times 4 \mu$.

3. C. albellus.

4. C. frustulosus.

5. C. griseus.

6. C. chromapes.

7. C. viscidus.

8. C. griseo-roseus.

פ. C. conicus.

Iо. C. Vanderbiltianus.

Stipe reticulate; pileus and stipe covered with a bright-yellow or scarlet tomentum or pulverulence.

II. C. Alaviporus.

I2. C. auriporus.

13. C. auriflammeus.

Tubes some shade of yellow or brown, rarely greenish, usually becoming darker with age (in C. fumosipes, C. sordidus, and C. Roxanae, the tubes are whitish when young).

Parasitic on species of Sclerodermu.

Found in clusters on roots and stumps of pine; pileus bright-golden-yellow.

Found on the ground, rarely on wood much de14. C. parasiticus.

15. C. hemichrysus. cayed and then not in clusters. 
Tubes stuffed when young, their mouths usually white; pileus usually glabrous.

Stipe furfuraceous, lilac-gray; pileus and tubes chocolate-brown.

Stipe smooth or reticulate; pileus and tubes of lighter color than above.

Spores brownish-ochraceous, $13-15 X$ 4-5 $\mu$; stipe more or less reticulate.

Spores ferruginous-ochraceous, 9-12 $\times$ 4-5 $\mu$; stipe rarely reticulate at the top; pileus often olivaceous and spotted.

Tubes not stuffed when young.

Pileus distinctly viscid, glabrous, yellow or fulvous, sometimes more or less reddish-brown; stipe not reticulate.

Tubes brick-colored, flesh peppery; stipe solid, yellow at the base.

Tubes yellow, flesh mild.

Stipe hollow, glabrous.

Stipe solid, dotted with yellow or red glandules.

Stipe solid, not dotted.

Tubes pale-greenish; a tropical species. Pileus glabrous or subtomentose, rarely papillate, not viscid.

Stipe reticulate, usually very distinctly so.

Pileus, tubes, and stipe tawnybrown.

Pileus red.

Context changing to blue when wounded.

Stipe bright-lemon-yellow throughout; pileus without a bloom.

Stipe red below, yellow above; pileus with a bloom.

Context not changing to blue when wounded.

Pileus chocolate-red, $3-4 \mathrm{~cm}$. broad.

Pileus testaccous, fading to ochraceous, 5-II cm. broad.

Pileus bay, conspicuously papillate, $12 \mathrm{~cm}$. broad.

Pileus yellow or brown; tubes yelJowish.

Temperate species.
16. C. eximius.

I7. C. crassus.

18. C. affinis.

I9. C. ferruginatus.

20. C. Curtisii.

21. C. inflexus.

22. C. Atkinsonianus.

23. C. jalapensis.
25. C. speciosus.

26. C. Peckii.

28. C. subsanguineus.

29. C. mirabilis. 
Tubes large; pileus subtomentose.

30. C. illudens.

Tubes of medium size; pileus usually glabrous.

Stipe white; pileus avellaneous-isabelline, very light in weight.

3I. C. subpallidus.

Stipe yellow or yellowishbrown.

Context yellow; spores II - I $4 \mu$ long.

32. C. retipes.

Context white, tinged with pink; spores 7-9 $\mu$ long.

33. C. alabamensis.

Tropical species.

Pileus $2-3 \mathrm{~cm}$. broad, floccose-tomentose.

34. C. guadalupensis.

Pileus $7 \mathrm{~cm}$. broad, glabrous.

Stipe not reticulate.

Pileus glabrous.

Pileus red; eastern species.

Stipe yellow, sometimes with red stains; entire plant quickly changing to blue a tany point where touched.

36. C. miniato-olivaceus.

Stipe red, yellow at the top; flesh and tubes slowly turning blue when wounded.

35. C. Maxoni.

37. C. bicolor.

Pileus bay; western species.

Context white, unchanging.

Context cremeous, unchanging.

38. C. oregonensis.

39. C. Zelleri.

Pileus yellow or brown.

Tubes changing to blue when wounded; stipe glabrous.

Tubes not changing to blue when wounded.

Stipe furfuraceous, paleyellow; tubes paleyellow to greenishyellow.

4I. C. subglabripes.

Stipe rough with minute, stiff, black hairs; tubes brown to black.

40. C. pallidus.

42. C. scabripes.

Pileus subtomentose; flesh usually spongy and drying readily.

Tubes not changing to blue when wounded. 
Tubes whitish, becoming yellow; mouths small, circular.

43. C. Roxanae.

Tubes yellow; mouths large and angular, especially near the stipe.

44. C. subtomentosus.

Tubes small, yellowish, becoming brick-red on drying or when bruised; pileus large, 9-13 cm. in diameter and $3 \mathrm{~cm}$. thick.

Tubes changing to blue when wounded.

Tubes at first grayish-white, discolored later by the spores; stipe bluishgreen at the top.

Pileus conspicuously reticulate-rimose.

Pileus not reticulate-rimose.

Tubes yellow and large; stipe and pileus usually red, the latter often cracked.

46. C. fumosipes.

47. C. sordidus.

48. C. communis.

\section{Ceriomyces Russellit (Frost) Murrill}

Pileus convex, $3-7 \mathrm{~cm}$. broad, $2-3 \mathrm{~cm}$. thick; surface dry, slightly viscid when moist, clothed with a thick tomentum agglutinated in raised squamules, presenting a reticulate appearance, often rimose-areolate, light-brown to isabelline with brown patches; context thin, cremeous, unchanging, taste mild, slightly salty; tubes plane, adnate or very slightly sinuate, depressed, cremeous when young, dark-flavous with a tinge of green at maturity, mouths large, angular, uniform, edges thin; spores ellipsoid, distinctly longitudinally striate, olivaceous, I5-I $7 \times 7-8 \mu$; stipe long and slender, tapering upward, very coarsely reticulate and fluted, the margins broad and lacerate, swelling in wet weather, somewhat glutinous even in dry weather, bright-pinkish-flesh-colored throughout, the depressions usually not darker, firm, solid or slightly stuffed, yellow within, $5^{-12} \mathrm{~cm}$. long, $\mathrm{I}-\mathrm{I} .5 \mathrm{~cm}$. thick at the base.

Occasional in open deciduous woods from New England to Mississippi and west to Wisconsin.

\section{Ceriomyces Betula (Schw.) Murrill}

Pileus hemispheric, $3-9 \mathrm{~cm}$. broad, $\mathrm{I}-2 \mathrm{~cm}$. thick; surface smooth, viscid, shining, perfectly glabrous, latericeous to almost 
luteous; margin acute, paler; context whitish, tinged with red or yellow, becoming reddish when bruised, slightly acid, not bitter; tubes nearly free, depressed at times, flavous, becoming darker at maturity, changing to greenish-yellow when wounded, mouths large, subcircular, somewhat unequal; spores melleous to olivebrown, papillate, oblong-ellipsoid, I6-20 $\times 7-9 \mu$; stipe tapering upward at the base, very long, pitted with long narrow depressions, giving it a shaggy appearance, flavous above and along the ridges, dull-purplish below, especially in the depressions, flesh solid, white or yellow with purplish tints, $10-20 \mathrm{~cm}$. long, $0.5^{-I} \cdot 5$ cm. thick.

Frequent in deciduous woods from North Carolina to Alabama and west to Tennessee, Ohio, and Kentucky.

\section{Ceriomyces albellus (Peck) Murrill}

Pileus circular, convex, subcespitose, 2-4 cm. broad; surface white or grayish-white with more or less bloom, sometimes paleavellaneous-isabelline, occasionally violet-gray when young, glabrous or subglabrous, dry; margin thin, regular, fertile, concolorous; context white or whitish, tinged with yellow at times, unchangeable; tubes plane, adnate, slightly depressed at times, rather short, white, violet-gray at times when young, becoming pale-yellow and sometimes darker-yellow from the maturing of the spores, mouths small, nearly circular, regular, edges rather thick, entire; spores oblong-ellipsoid, brownishochraceous, I4-I6 $\times 5^{-6 \mu}$; stipe central, cylindric, equal, sometimes thickened at the base, white or whitish, glabrous or nearly so, usually distinctly reticulate in the upper half, but rarely smooth or somewhat striate except at the very top, $3-5 \mathrm{~cm}$. long, 5-Io mm. thick.

Occasional in deciduous woods from New York to Virginia and Tennessee.

\section{Ceriomyces frustulosus (Peck) Murrill}

Pileus thick, convex or nearly plane, $2.5^{-5} \mathrm{~cm}$. broad; surface white or whitish, subglabrous, rimosely arcolate, the arcolae unequal and appearing like frustra of polygonal pyramids; context whitish, unchanging; tubes depressed, whitish, becoming pale-brown, equaling the thickness of the context; spores fusi-

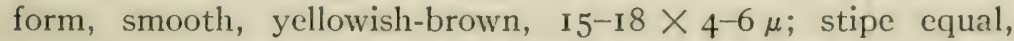
whitish, reticulate above and sometimes nearly or quite to the base, solid, $2.5-5 \mathrm{~cm}$. long, $\mathrm{I}-2 \mathrm{~cm}$. thick.

Occasional on clay banks and open ground in Mississippi and Alabama. 


\section{Ceriomyces griseus (Frost) Murrill}

Pileus broadly convex, $5^{-10} \mathrm{~cm}$. in diameter; surface subglabrous, smooth, dry, light- or dark-gray, rarely slightly brownish; context firm, whitish or grayish, yellowish in spots, unchanging; tubes adnate, slightly depressed, somewhat decurrent at times, pure-white or whitish, becoming brownish with age and darker when bruised; spores ellipsoid, smooth, ochraceousbrown, 9-I $4 \times 4-5 \mu$; stipe flexuous, whitish or yellowish, changing to brown when bruised, rarely reddish toward the base, distinctly reticulate, firm, stuffed, becoming hollow at times, 5-Io cm. long, $0.5^{-1.3} \mathrm{~cm}$. thick.

Occasional in open woods from New England to North Carolina. Edible.

\section{Certomyces chromapes (Frost) Murrill}

Pileus convex to expanded, $4^{-8} \mathrm{~cm}$. broad, $\mathrm{r} \mathrm{cm}$. or more thick; surface slightly tomentose, the fine, tangled fibers very distinct under a lens, pale-tan to rosy-isabelline or pale-red; margin acute to somewhat obtuse, concolorous; context white, unchanging, taste mild; tubes free or slightly attached, creamywhite to pale-brown or reddish-brown, becoming flesh-colored and finally brownish with age, mouths small, subcircular, concolorous; spores oblong-ellipsoid, smooth, subhyaline, II-I4 $\times 4^{-5} \mu$; stipe equal, tapering above, pallid or pinkish with red or brown scales, bright-yellow at the base, rarely entirely yellow, sometimes faintly reticulate above, solid, bright-yellow within, especially at the base, $6-9 \mathrm{~cm}$. long, $\mathrm{I}-1.5 \mathrm{~cm}$. thick.

Common in open woods from Nova Scotia to Georgia and Mississippi. Edible.

\section{Ceriomyces viscidus (L.) Murrill}

Pileus convex, thick, fleshy, 4-Io $\mathrm{cm}$. broad, I.5-3 cm. thick; surface smooth, glabrous or minutely tomentose, slightly viscid when moist, varying in color from white to shades of brown or red; margin thick, subacute, sometimes appendiculate; context $1.5 \mathrm{~cm}$. thick at the center, white or whitish, becoming fleshcolored or slightly darker when bruised, taste mild; tubes long, slender, free or nearly so, depressed, white or greenish-yellow, becoming brownish with age and flesh-colored or blackish when bruised, mouths circular, edges thin; spores oblong, smooth, snuff-brown, 13-16 $\times 4-6 \mu$; stipe firm, solid, tapering upward, bulbous at the base, whitish, especially above, brownish-cinereous below, roughened with numerous reddish or brownish dots or scales, $5^{-15} \mathrm{~cm}$. long, $\mathrm{I}-2 \mathrm{~cm}$. thick. 
Extremely common throughout temperate North America in woods and groves. An edible species easily recognized by its, rough stipe.

\section{Ceriomyces griseo-Roseus Murrill}

Pileus irregularly convex, $7 \mathrm{~cm}$. broad; surface even, slightly viscid when moist, light-grayish-flesh-colored; margin thin, entire, fertile; context white, unchanging, mild; tubes concolorous, slightly sinuate, nearly plane in mass, mouths small, angular, edges thin; spores oblong-ellipsoid, almost rod-shaped, with rounded ends, smooth, yellowish-brown, II-I3 $32.5-3 \mu$; stipe concolorous, tapering upward, somewhat fibrous, subglabrous, even, hollow or stuffed, $7.5 \mathrm{~cm}$. long, nearly $2 \mathrm{~cm}$. thick.

Collected once near Mobile, Alabama.

\section{Ceriomyces conicus (Rav.) Murrill}

Pileus convex or subcentic; $2.5^{-5} \mathrm{~cm}$. broad; surface clothed with fasciculate, appressed, yellowish flocci; context white, unchangeable, tasteless; tubes ventricose, flesh-colored, becoming darker at the maturity of the spores, mouths small, angular, edges subfimbriate; spores fusiform, smooth, subferruginous, I4-16 $\times 5^{-6 \mu}$; stipe tapering upward, pale-yellow, glabrous, not reticulate, $5 \mathrm{~cm}$. long, $12 \mathrm{~mm}$. thick.

Known only from the original collection in damp pine woods in South Carolina.

\section{io. Ceriomyces Vanderbiltianus Murrill}

Pileus subconic, $2-3 \mathrm{~cm}$. broad, $\mathrm{I}-2 \mathrm{~cm}$. thick; surface smooth, dry, conspicuously ornamented on the umbo with dense, pointed, imbricate, dark-purple scales, which become gradually smaller and give place to minute purplish specks near the margin, the color changing from atropurpureous to latericeous; margin thin, undulate, pale-roseous, with a distinct inflexed sterile portion I $\mathrm{mm}$. broad; context thick, fleshy, firm, cream-colored, unchangeable, taste sweet or very slightly bitter; tubes adnate, the longest not over $4 \mathrm{~mm}$., salmon-colored near the niargin, incarnate as the spores mature, mouths angular, I mm. or less broad, elongate to $2 \mathrm{~mm}$. near the stipe, edges thin, entire; spores oblong-ellipsoid, smooth, pale-ochraccous-brown, 9-I2 $\times 2-3 \mu$; stipe curved, cylindric, slightly enlarged above, even, delicately pruinose to glabrous, deep-salmon-colored, changing to incarnate, darker on bruising, lighter above with a slight glaucous bloom, finely purplish-dotted like the margin of the 
pileus, solid and cream-colored within, $2-3 \mathrm{~cm}$. long, $0.5-0.8$ $\mathrm{cm}$. thick.

Known only from Pink Bed Valley, North Carolina, occurring by the roadside in thin oak woods.

\section{Ceriomyces flaviporus (Earle) Murrill}

Pileus rather thin, convex to expanded, $6-9 \mathrm{~cm}$. broad; surface smooth, viscid, not glutinous, shining, chestnut-brown; context whitish to brownish, unchanging, taste mild; hymenium plane, tubes usually deeply depressed, but decurrent for nearly $\mathrm{I} \mathrm{cm}$. in anastomosing lines, bright-lemon-yellow when young, becoming deep-yellow or flavid with age and retaining this color in dried specimens, mouths small, I mm. broad, angular, edges thin; spores narrowly ellipsoid, smooth, yellow, $15 \times 6 \mu$; stipe subequal or slightly ventricose, yellowish and smooth or marked with glutinous granules above, tomentose and white stained with brick-red below, solid, 6-9 cm. long, I.8 cm. thick.

Occasional under oaks in California.

\section{i2. Ceriomyces auriporus (Peck) Murrill}

Pileus circular, plano-convex, $2-4 \mathrm{~cm}$. broad, $0.5^{-1} \mathrm{~cm}$. thick; surface reddish-brown or yellowish-brown, rarely grayish-brown, sometimes brown with a reddish-yellow tint or reddish-brown in the center and olivaceous toward the margin, glabrous or minutely tomentose, slightly areolate at times with age, the interstices appearing yellow, usually dry, but somewhat viscid in wet weather; margin even, thin, somewhat obtuse, slightly inflexed on drying, concolorous; context firm, fleshy, 3-5 mm. thick, white, unchangeable, tinged with red under the cuticle, at first mild, then unpleasant to the taste, the cuticle decidedly acid; tubes plane or convex, adnate or nearly free, with a broad shallow depression about the stipe, 3-5 $\mathrm{mm}$. long, bright-golden-yellow, unchanging, even after years in the herbarium, mouths concolorous, variable in size, small and circular when young, medium or large and irregularly polygonal when old, edges thin, entire; spores oblong-ellipsoid, curved at one end, lemon-yellow, 8-Io $\times 4^{-5} \mu$; stipe central, short, slender, curved, tapering upward, nearly glabrous, pulverulent under a lens, slimy in wet weather, concolorous or paler, slightly striate above from the decurrent edges of the tubes, solid, white or discolored-yellowish tinged with red within, $2-4 \mathrm{~cm}$. long, 4-8 mm. thick.

Common in thin, dry woods from New England to Alabama and west to the Rocky Mountains. Edible. 


\section{I3. Ceriomyces auriflammeus (Berk. \& Curt.) Murrill}

Pileus convex to expanded, 6-8 cm. broad, $\mathrm{I}-2 \mathrm{~cm}$. thick; surface dry, slightly viscid after a rain, tomentose, brightyellow, sometimes partly covered with a scarlet pulverulence; margin thin, entire; context white, unchangeable, somewhat colored just beneath the pellicle, not bitter; tubes plane or convex, adnate, radially elongate near the stipe, decurrent, greenishyellow, mouths angular, usually slightly scarlet when looked at sidewise, especially in dried plants, rarely conspicuously scarlet over most of the hymenium; spores pale-yellow, smooth, oblongellipsoid, 9-II $\times 3-4 \mu$; stipe enlarged above, usually tapering below, but sometimes bulbous, very variable in size, $5-9 \mathrm{~cm}$. long, $0.5^{-1} \mathrm{~cm}$. thick, colored and clothed like the pileus, distinctly and beautifully reticulate, sometimes entirely to the base.

Occasional on thin soil in deciduous woods in New York, Pennsylvania, Kentucky, and North Carolina. Very beautiful.

\section{i4. Ceriomyces parasiticus (Bull.) Murrill}

Pileus convex to expanded, $5^{-8} \mathrm{~cm}$. broad; surface dry, finely tomentose to glabrous, becoming tessellately rimose, dingyyellow or cinereous; context whitish; tubes decurrent, of medium size, golden-yellow; spores fusiform, smooth, pale-brownish, I2-I $5 \times 4 \mu$; stipe incurved, glabrous, solid, yellow without and within, 4-10 $\mathrm{cm}$. long, $0.5^{-1} \mathrm{~cm}$. thick.

Occasional on species of Scleroderma in New England and New York.

\section{I5. Ceriomyces hemichrysus (Berk. \& Curt.) Murrill}

Pileus convex, becoming plane or slightly depressed, $3^{-7} \mathrm{~cm}$. broad; surface floccose-squamulose, golden-yellow, pulverulent, at times rimose; context thick, yellow, sometimes slightly changing to blue when wounded; tubes adnate or decurrent, yellow, becoming reddish-brown, mouths large, angular; spores oblong-ellipsoid, smooth, pale-yellowish-brown, $7-9 \times 2-3 \mu$; stipe short, irregular, tapering below, yellowish-pulverulent, tinged with red, yellow within, $3 \mathrm{~cm}$. long, $0.5^{-1} \mathrm{~cm}$. thick.

Occasional on pine roots and stumps in New York, New Jersey, the Carolinas, and Alabama.

\section{i6. Ceriomyces eximius (Peck) Murrill}

Pileus thick, compact, globose when young, becoming convex at maturity, 8-20 cm. broad; surface dry, smooth, subglabrous, 
slightly viscid when wet, purplish-brown, smoky-red or chocolate-brown, at times lilac-tinged, darker when bruised; margin entire, concolorous; context firm, gray or slightly reddish, sometimes nearly pure-white, changing to pale-flesh-colored, taste mild; tubes adnate, at length depressed, nearly plane, colored nearly like the pileus, becoming deep-chocolate-brown with age, mouths minute, subcircular, stuffed when young; spores oblong, smooth, brownish-ferruginous, I I-I $5 \times 4-6 \mu$; stipe cylindric, subequal, solid, minutely squamulose or coarsely granular, slightly paler than the pileus, greenish-purple within, 5-I4 cm. long, I-3 cm. thick.

Frequent in thin woods and on roadside banks from Nova Scotia to North Carolina and west to Kentucky.

\section{Ceriomyces crassus Batt.}

Pileus thick, broadly convex, gregarious or cespitose, 6-20 $\mathrm{cm}$. broad, 3-4 cm. thick; surface smooth, glabrous or finely tomentose, subopaque, dry, slightly viscid when moistened, sometimes pitted or reticulate-rimose, varying in color from ochraceous-brown to reddish-brown, sometimes paler; margin acute, entire; context compact, $2-3 \mathrm{~cm}$. thick, unchanging, white or yellowish, sometimes reddish beneath the cuticle, taste sweet and nutty; tubes adnate, at length depressed, plane in mass, white and stuffed when young, yellow or greenish-yellow when mature, changing to greenish-ochraceous when wounded, about $2 \mathrm{~cm}$. long, mouths of medium size, angular, edges thin; spores fusiform, smooth, greenish-yellow to ochraceous-brown, I2-I $5 \times 5^{-6 \mu}$; stipe subequal or enlarged below, stout, concolorous or considerably paler, becoming bluish or discolored when wounded, wholly or partially reticulate, solid, tough, fibrous, yellowish within, tinged with red at times near the surface, 5-10 $\mathrm{cm}$. long, 3-4 cm. thick.

Very common in woods and groves throughout temperate North America. One of the very best edible fungi, and much used for food in other countries.

\section{r8. Cériomyces AfFinis (Peck) Murrill}

Pileus convex to plane, gregarious or scattered, 5-9 $\mathrm{cm}$. broad; surface glabrous or nearly so, slightly viscid when moist, but usually dry, with a thin, separable cuticle which easily cracks or rubs off in spots, fulvous, pale-chestnut, ocluraceous, or somewhat olivaccous; margin rather obtuse, entire, slightly projecting beyond the tubes; context somewhat spongy, white, 
unchanging or sometimes slowly becoming yellowish, taste mild; tubes adnate to nearly free, about I cm. long, white or cremeous, becoming subferruginous when wounded or at the maturity of the spores, mouths somewhat uneven, $2-3$ to a mm., subcircular to angular, stuffed when young; spores oblong, smooth, brightferruginous-ochraceous, 8-I2 $\times 4-5 \mu$; stipe cylindric; tapering downward, usually slightly eccentric, rarely reticulate above, glabrous, white above and below, flesh-colored and more or less streaked in the middle, spongy and white within, about $7 \mathrm{~cm}$. long and $\mathrm{I} .5 \mathrm{~cm}$. thick.

Frequent in thin woods from Vermont to North Carolina and west to Indiana.

\section{I9. Ceriomyces ferruginatus (Batsch) Murrill}

Pileus convex to plane or nearly so, umbonate when young, circular in outline, $2-5 \mathrm{~cm}$. broad, reaching $7 \mathrm{~cm}$. at times; surface smooth, glabrous, sometimes rimose-areolate, slightly viscid in damp weather, varying from ochraceous to fulvous; margin regular, entire, sometimes quite thick because of the lengthening of the marginal tubes; context thickest at the center and gradually thinner toward the margin, yellow or yellowishwhite for the most part, but light-pink or roseous next to the layer of tubes, darker when exposed to the air, acrid and peppery, remarkably free from insects; tubes adnate, at length depressed around the stipe, latericeous, becoming slightly darker when wounded, tinged with ferruginous at the maturity of the spores, equal to or longer than the thickness of the context, mouths large, angular, unequal; spores subfusiform, ferruginous, 9-I I $\times 4 \mu$; stipe central, slender, nearly equal, $2-5 \mathrm{~cm}$. long, 4-5 $\mathrm{mm}$. thick, rarely reaching $7 \mathrm{~cm}$. in length and $8 \mathrm{~mm}$. in thickness, pulverulent, slightly veined above, smooth below, usually somewhat paler than the pileus, citrinous or flavous at the base, solid, fleshy, and yellow within.

Frequent in woods and open places throughout the northern United States and Canada to the Pacific coast. Acrid and peppery and considered poisonous.

\section{Ceriomyces Curtisir (Berk.) Murrill}

Pileus hemispheric, $2-5 \mathrm{~cm}$. broad, $1.5^{-2} \mathrm{~cm}$. thick; surface glabrous, viscid, golden-yellow, changing to dull-brownish when old, cuticle very tough, margin involute in young specimens; context thin, white, pale-yellow when bruised; tubes adnate to nearly free, plane or subventricose in mass, slightly decurrent, 
small, I cm. long, light-salmon-yellow changing to brownishyellow, mouths circular, edges thin; spores subellipsoid, smooth, ferruginous, $12-13 \times 5^{-7} \mu$; stipe subcylindric, slender, attenuate above, straw-colored or bright-yellow, nearly white at the base, viscid, glabrous, polished, reticulate, usually hollow, 2-10 $\mathrm{cm}$. long, $0.5-0.8 \mathrm{~cm}$. thick.

Occasional in pine woods from Kentucky to South Carolina, Alabama, and Mississippi.

\section{I. Ceriomyces inflexus (Peck) Murrill}

Pileus convex, sometimes cespitose, $2.5^{-4} \mathrm{~cm}$. broad; surface glabrous, viscid when wet, yellow or olivaceous becoming ochraceous-brown, often reddish on the disk; margin thin, inflexed, concealing the marginal tubes; context white, unchanging, taste mild; tubes adnate, somewhat depressed, yellowish, becoming dingy-yellow with age and somewhat reddish-brown when injured, rather long, mouths $3-4$ to a mm., circular, sometimes dotted with reddish granules; spores oblong, smooth, yellowishbrown, IO-I $2 \times 4-5 \mu$; stipe rather slender, curved, tapering above, 5-7 cm. long, $0.4-0.8 \mathrm{~cm}$. thick, viscid, reddish-brown with dark fibrils or dots, pale-yellowish above and below, solid, white to pale-yellowish within.

Occasional in open woods from Connecticut to North Carolina and Kentucky.

\section{Ceriomyces Atrinsonianus Murrill}

Pileus convex to nearly plane, 9-14 cm. broad, about $2.5 \mathrm{~cm}$. thick; surface smooth, glabrous, viscid when wet, sometimes becoming rimose-areolate, leather-colored to fulvous, often with a pinkish tint; margin inrolled when young, extending $3 \mathrm{~mm}$. beyond the tubes, entire at first, slightly hoary; context white, becoming pale-rose-colored when wounded, sweet to the taste; tubes adnate, plane in mass, becoming slightly depressed near the stipe, straw-colored in young plants, not changing when wounded, becoming olivaceous with age owing to the ripening of the spores, mouths small, circular, concolorous, 4-5 to a $\mathrm{mm}$., not stuffed when young, edges thin, entire; spores fusiform, smooth, dark-olivaccous to dull-brownish in mass, $\mathrm{II}-\mathrm{I} 3 \times 4-5 \mu$; stipe tapering upward, somewhat bulbous at the base, glabrous, even, subconcolorous, cartilaginous, pale-yellow at the apex, solid, white and unchanging within, about $9^{-12} \mathrm{~cm}$. long and I $-3 \mathrm{~cm}$. thick. 
Frequent in deciduous woods in Pink Bed Valley, western North Carolina, and in certain parts of New York.

\section{Ceriomyces Jalapensis Murrill}

Pileus small, convex, circular in outline, $2.2 \mathrm{~cm}$. in diameter, I cm. thick; surface isabelline to fulvous, slimy, smooth; context white to faintly-roseous, mild to the taste, $2 \mathrm{~mm}$. thick behind; hymenium convex, depressed in the form of a crater about the stipe; tubes pale-greenish, $7 \mathrm{~mm}$. long, mouths large, rounded, I-2 to a mm., edges thin; spores ellipsoid, deep-ferruginous, distinctly longitudinally striate, copious, I3-I $5 \times 7^{-9} \mu$; stipe central, slender, tapering upward, concolorous, smooth, glabrous, not conspicuously slimy like the pileus, swollen and white at the base, $6 \mathrm{~cm}$. long, $4 \mathrm{~mm}$. thick at the middle.

Found near Jalapa, Mexico, on the ground in a virgin forest.

\section{Ceriomyces tabacinus (Peck) Murrill}

Pileus convex, 6-I $2 \mathrm{~cm}$. broad; surface dry, finely tomentose, often becoming rimose-areolate, wood-brown to dark-cinnamonbrown; context white, firm, unchanging when wounded, soft and tawny-brown, almost tomentose in texture at maturity, taste mild; tubes sinuate, short, concave or nearly plane in mass, mouths small, angular or subcircular, whitish-stuffed when young, becoming pale-yellowish-brown; spores very slender, smooth, pale-yellowish, $12 \times 3 \mu$; stipe at first almost globose, becoming subequal, thick, slightly tapering above, concolorous, reticulate, solid, $4-8 \mathrm{~cm}$. long, I-3 $\mathrm{cm}$. thick.

Occasional in red clay on the banks of ditches in Alabama.

\section{Ceriomyces speciosus (Frost) Murrill}

Pileus thick, compact, subglobose to convex, $7-15 \mathrm{~cm}$. broad; surface glabrous or subglabrous, smooth, slightly moist, red; context firm, lemon-yellow, changing to greenish-blue when wounded and afterwards changing back to yellow, taste nutty; tubes adnate, plane or slightly depressed, lemon-yellow, becoming dingy with age, changing to blue when wounded, mouths small, circular; spores fusiform, smooth, pale-ochraceous-brown, I0-12 $\times 4-5 \mu$; stipe stout, solid, reticulate, vivid-lemon-yellow without and within, slightly reddish at the base at times, 5-10 $\mathrm{cm}$. long, 2-5 cm. thick.

Frequent in thin deciduous woods from New England to North Carolina and Tennessee. It is well named. 


\section{Ceriomyces Peckil (Frost) Murrill}

Pileus rather thick, firm, convex or nearly plane, $4-7 \mathrm{~cm}$. broad; surface dry, subglabrous to pruinose or slightly velvety, pale- or deep-red, usually fading to pale-tan or buff-brown with age or on drying; margin incurved, entire, concolorous; context firm, white or yellowish, bluish when bruised, taste unpleasant; tubes short, adnate or slightly decurrent, nearly plane in mass, yellow, changing to blue when wounded, mouths minute, circular, edges uneven; spores oblong, smooth, pale-ochraceous-brown, IO-I2 $\times 4-5 \mu$; stipe equal or subventricose, usually yellow above, red or purplish-red below or the entire length, reticulate, especially above, solid, 4-7 cm. long, $0.5^{-1.2} \mathrm{~cm}$. thick.

Common in open deciduous woods from New England to North Carolina and west to Indiana. Reported edible.

\section{Ceriomyces Housei Murrill}

Pileus convex above, nearly plane below, $3-4 \mathrm{~cm}$. broad, $\mathrm{I} \mathrm{cm}$. thick; surface smooth, dry, minutely tomentose, chocolate-red with a velvety sheen; margin concolorous above, slightly overlapping the tubes, reddish beneath; context firm, solid, white, unchanging; tubes decurrent, never depressed, clear-yellow when young, dull-yellow with age, not changing when wounded, 2-4 mm. long, mouths of medium size, circular to oblong, never angled, edges thin, entire; spores smooth, oblong-ellipsoid, yellowish, with a large, hyaline nucleus, $7-9 \times 4-5 \mu$; stipe central, cylindric, equal, subglabrous, yellow and distinctly reticulate above, dull-chocolate-brown below, the base frequently mottled with yellow, solid and unchanging within, $3-5 \mathrm{~cm}$. long, 5-8 $\mathrm{mm}$. thick.

Known only from Pink Bed Valley, North Carolina, growing on mossy banks in deciduous thickets.

\section{Ceriomyces subsanguineus (Peck) Murrill}

$\therefore$ Pileus convex to plane or slightly depressed, gregarious or cespitose, 5-I I cm. broad, I-3 cm. thick; surface usually glabrous, somewhat viscid, testaceous, fading to ochraccous or isabelline, rarely pulverulent or partially rimose-areolate; margin obtuse, beveled; context thick, white, firm, changing slightly to very pale roscous when wounded, slightly harsh or bitterish at first to the taste, but becoming mild; tubes truly adnate, separating slightly in old plants, decurrent, 5-7 $\mathrm{mm}$. long, pale-ycllowish, becoming brownish to purplish when bruised, mouths of merlium size, edges thin; spores oblong-ovoid, 
smooth, very pale yellowish, $8-9 \times 3.5-4.5 \mu$; stipe rather short, thick, tapering downward to a small radicate base, $4-7 \mathrm{~cm}$. long, I-2 cm. thick, nearly white, finely scurfy, sometimes reddish-dotted, flavous and reticulate above, solid, firm and white within.

Found under beech trees in Philadelphia, Pennsylvania.

\section{Ceriomyces mirabilis Murrill}

Pileus convex, spongy, solitary or gregarious, reaching $12 \mathrm{~cm}$. in diameter; surface moist, bay, uniformly covered with conspicuous, projecting, conic, floccose, persistent papillae, which give it somewhat the appearance of bread-fruit; margin projecting like the eaves of a house, showing a yellow membrane 2-3 $\mathrm{mm}$. wide; context citrinous, slowly changing to incarnate when bruised, very watery, drying with difficulty, tasteless; tubes large, greenish-yellow, uneven; spores fusiform, smooth, ochraceousmellous, I9 $\times 7 \mu$; stipe very bulbous, solid, bay and streaked below, strongly reticulate and latericeous above, the apex colored like the tubes, $15 \mathrm{~cm}$. long, $1.3 \mathrm{~cm}$. thick above, $3.5 \mathrm{~cm}$. thick below.

This remarkable species was found several times in the vicinity of Seattle, Washington, on the ground in woods. It is one of the most difficult species to preserve, owing to its extremely juicy consistency. It differs from nearly all other boleti in its floccose covering, which resembles that found on the surface of Boletellus Ananas and Strobilomyces strobilaceus, but the scales are more rigid and conic in shape. The collector may readily distinguish it from these two species by its bay color and the absence of a veil.

\section{Ceriomyces illudéns (Peck) Murrill}

Pileus convex, $3-7 \mathrm{~cm}$. broad; surface dry, finely tomentose, olivaceous, yellowish-brown or grayish-brown, sometimes slightly tinged with red, especially in the center; context whitish or yellowish, unchanging, rather spongy; tubes plane or convex in mass, adnate to adnexed, bright-yellow to melleous without and within, mouths large, angular or subcircular, usually larger near the stipe; spores oblong or subfusiform, olive-green fading to yellowish-brown tinged with green, II-I $3 \times 4^{-5} \mu$; stipe nearly equal, usually tapering at the base, glabrous, whitish or yellowish to light-bay above, pale-yellow below, $3-7 \mathrm{~cm}$. long, $5^{-10} \mathrm{~mm}$. thick, coarscly reticulate entirely to the base in fully developed specimens, but only at the apex in small plants. 
Frequent in woods and copses from Vermont to Alabama and reported as far west as Missouri.

\section{Ceriomyces subpallidus Murrill}

Pileus hemispheric, only slightly expanding, $5 \mathrm{~cm}$. broad, $2 \mathrm{~cm}$. thick; surface dry, smooth, glabrous, feeling very much like soft kid, avellaneous-isabelline, not becoming white-spotted nor having a separable pellicle; margin entire, fertile, the tubes slightly projecting; context milk-white, entirely unchanging, very light in weight, spongy-fleshy; tubes yellow or greenishyellow within, equaling the thickness of the context, adnate, plane in mass, becoming somewhat depressed next to the stipe, mouths dark-melleous, becoming browner with age, slightly angular, of medium size; spores fusiform, smooth, pale-ochraceous under a microscope from dried specimens, IO-I $2 \times 4-5 \mu$; stipe cylindric, equal, curved at the base, white, delicately but distinctly reticulate nearly to the base, slightly pruinose, solid, white and unchanging within, about $5 \mathrm{~cm}$. long and I cm. thick.

Known only from Pink Bed Valley in western North Carolina, growing under oaks and chestnuts.

\section{Ceriomyces retipes (Berk. \& Curt.) Murrill}

Pileus convex above, concave or plane beneath, rarely cespitose, 5-I2 cm. broad, I-2 cm. thick; surface dry, opaque, somewhat viscid when wet, minutely tomentose to glabrous, sometimes covered with a yellow pulverulence, varying in color from yellow or yellowish-brown to fuliginous; context firm, lightto deep-yellow, unchanging, mild or slightly bitter; tubes adnate, slightly decurrent, somewhat depressed with age, $\mathrm{I} \mathrm{cm}$. or more long, clear-lemon-yellow when young, becoming dull-yellow at maturity, darker with age, but not changing when wounded, mouths circular to angular, less than I $\mathrm{mm}$. broad, slightly flesh-colored when bruised; spores oblong, smooth, yellowishbrown, II $-14 \times 3-4.5 \mu$; stipe subequal, often bulbous at the base, distinctly and beautifully reticulate, sometimes entirely to the base, yellowish-pulverulent in some specimens, yellow and firm within, yellow or yellowish-brown without, $5^{-12} \mathrm{~cm}$. long, $0.5^{-2} \mathrm{~cm}$. thick.

Common in thin woods from Nova Scotia to Alabama and west to Wisconsin and Missouri.

\section{Ceriomyces alabamensis Murrill}

Pilcus plane when expanded, solitary, $7 \mathrm{~cm}$. broad; surface smooth, glabrous, ycllowish-brown, with partially separable 
cuticle; margin thin, fertile, subentire; context white, tinged with pink; tubes adnate, decurrent, yellowish when young, stained brown with the spores at maturity, mouths rather large, angular, irregular; spores oblong-ellipsoid, smooth, yellowishbrown, 7-9 $\times 3-4 \mu$; stipe eccentric, flexuous, slightly tapering below, $7 \mathrm{~cm}$. long, I. $3 \mathrm{~cm}$. thick, concolorous, glabrous, reticulate above with brown lines.

Known only from Auburn, Alabama.

\section{Ceriomyces guadalupensis (Pat.) Murrill}

Pileus small, fleshy, convex, $2-3 \mathrm{~cm}$. broad; surface chestnutbrown, very finely tomentose, adorned with short, erect, floccose filaments; margin incurved, thin, appendiculate, paler; context thin, yellowish, reddish beneath the cuticle; tubes short, yellowish-brown, mouths small, angular; spores very long, oblongovoid, smooth, rounded at the apex, apiculate at the base, ochraceous, I- or 2-guttulate, I6-20 $\times 6-8 \mu$; cystidia prominent, cylindric, yellow; stipe slender, ventricose, yellow with red striations, marked with fine, close ribs.

Found on decayed wood in Guadeloupe.

\section{Ceriomyces Maxoni Murrill}

Pileus irregularly circular in outline, convex, slightly depressed, $7 \mathrm{~cm}$. broad, $I-I .5 \mathrm{~cm}$. thick; surface glabrous, smooth, very dark brown, almost black near the margin, slightly lighter at the center with dark blotches, margin undulate, involute; context very fleshy; hymenium strongly concave, pure-creamywhite, tubes adnate, rather short, small, angular, thin-walled, edges becoming lacerate; spores oblong-ellipsoid, smooth, hyaline, 2-guttulate, 9-I I $\times 3^{-4 \mu}$; stipe central, thick, tapering downward, $2.5 \mathrm{~cm}$. long, $3 \mathrm{~cm}$. thick above, I. $5 \mathrm{~cm}$. thick at the base, smooth and glabrous below, closely and conspicuously reticulate above, fleshy, solid.

Found among mosses on a rotten log at Coliblanco, Costa Rica.

\section{Ceriomyces miniato-olivaceus (Frost) Murrill}

Pileus firm, convex, becoming nearly plane and somewhat spongy with age, cespitose, $5^{-1} 5 \mathrm{~cm}$. broad; surface finely tomentose to glabrous, sometimes rimose-areolate, vermilion, becoming olivaceous or ochraceous-red, changing to blue when handled; margin acute, slightly exceeding the pores; context pale-yellow, changing immediately to blue when wounded, mild or slightly 
unpleasant to the taste, said to be poisonous; tubes adnate or subdecurrent, slightly depressed, bright-lemon-yellow tinged with green, becoming brownish-yellow with age, changing to blue when wounded, mouths subangular, of medium size; spores oblongellipsoid, smooth, yellowish-brown, I0-I $3 \times 4-6 \mu$; stipe equal or enlarged above or below, pale-yellow with pink markings, especially near the base, glabrous, faintly reticulate at the apex, solid, yellow within, 6-Io $\mathrm{cm}$. long, $0.5-\mathrm{I} .5 \mathrm{~cm}$. thick.

Frequent in open woods and groves from Maine to North Carolina. Somewhat poisonous, but readily recognized among the red boleti by its quick change to blue at any point without or within when bruised or even touched with the fingers. It is often known as the sensitive boletus.

\section{Ceriomyces bicolor (Peck) Murrill}

Pileus somewhat irregular, firm, convex, $5-10 \mathrm{~cm}$. broad; surface dry, glabrous or finely tomentose or squamulose, at times rimose-areolate with age, apple-red or purplish-red, often fading or becoming stained with yellow when old; margin irregular, sometimes upturned; context flavous, changing slowly to blue at times when wounded, then back to flavous, taste mild; tubes short, adnate, nearly plane, flavous when young, becoming ochraceous with age, changing slowly to blue or greenish-blue when wounded, mouths angular, of medium size, 2-3 to a mm.; spores fusiform, smooth, pale-ochraceous-brown, IO-I $2 \times 4-5 \mu$; stipe nearly equal, firm, solid, dark, usually yellow and sometimes slightly reticulate at the apex, changing to greenish-blue when bruised, smooth, nearly glabrous, showing dark dots under a lens, solid, flavous within, changing slowly to blue, 4-IO cm. long, $0.7-1.5 \mathrm{~cm}$. thick.

Frequent in open woods from New England to North Carolina and west to Wisconsin and Kentucky. Edible.

\section{Ceriomyces oregonensis Murrill}

Pileus convex, firm, solitary, $12 \mathrm{~cm}$. broad; surface bay, even, not viscid, short-tomentose to subglabrous, margin entire or slightly lobed, scarcely projecting: context firm, white, unchanging, taste mild, odor not characteristic; tubes very large, 2-3 $\mathrm{mm}$. in diameter, depressed and radially elongate about the stipe, ventricose, flavous to dull-greenish-ycllow, melleous within, not changing when bruised; spores oblong-ellipsoid, smooth, mellenus, Io-1 $2 \times 4 \mu$; stipe larger below, solid, white within, glabrous, not reticulate, very pale bay, $6.5 \mathrm{~cm}$. long, $2 \mathrm{~cm}$. thick at the center. 
This species was collected on the ground in sandy pine barrens on the immediate coast at Newport, Oregon. Although growing in sand, the weather conditions were very humid.

\section{Ceriomyces Zelleri Murrill}

Pileus convex, firm, gregarious to subcespitose, $7-9 \mathrm{~cm}$. broad; surface dry, uneven, bay, covered with a delicate bloom which disappears with age; margin regular, concolorous, somewhat projecting; context firm, cremeous, unchanging, drying easily, mild and slightly mucilaginous to the taste; tubes irregular, of medium size, pale-yellow to greenish-yellow, scarcely changing when bruised; spores fusiform, smooth, ochraceous, averaging 12 $\times 4.5 \mu$; stipe bulbous, solid, red to purple, white or yellow at the base, more or less striate, furfuraceous, about $5 \mathrm{~cm}$. long and I. $5 \mathrm{~cm}$. thick.

This species is very common about Seattle, Washington, on rather dry banks in woods, and has also been found in California. When fully mature, the bloom on the cap disappears and the color is so dark that the sporophore is difficult to see unless a glimpse of the yellow hymenium is obtained.

\section{Ceriomyces pallidus (Frost) Murrill}

Pileus circular, convex to plane cr depressed, $5^{-12} \mathrm{~cm}$. broad; surface smooth, dry, glabrous, rather soft to the touch, pallid or grayish-brown, slightly tinged with red at times; margin even, regular, rather thin, fertile, concolorous or paler; context white, becoming slightly bluish when wounded; tubes nearly adnate, plane or depressed, rarely becoming free, of medium length, very pale yellowish, becoming dark-flavous with age from the ripe spores, changing to blue when wounded, mouths small, angular to irregular, becoming uneven from the lengthening of the thin dissepiments into tooth-like projections; spores oblong-ellipsoid, smooth, ochraceous-brown, IO-I $3 \times 4-5 \mu$; stipe usually slender, cylindric, tapering upward, glabrous, even, nearly white, streaked with brown or red, at times tinged with purple and flesh-color, often reddish within, especially near the base, 6-I $5 \mathrm{~cm}$. long, 7-I $5 \mathrm{~mm}$. thick.

Frequent in woods from New England to Alabama.

\section{I. Ceriomyces subglabripes (Peck) Murrill}

Pileus circular, rather thin, subconic or convex to nearly plane, occasionally cespitose, 3-1o $\mathrm{cm}$. broad; surface glabrous, 
subviscid when moist, rugose at times, usually so when dry, reddish, pale-chestnut, grayish-brown, golden-brown, or rarely darker-brown; margin regular, concolorous; context white or whitish, unchangeable, of mild flavor; tubes plane or convex, adnate or depressed, lemon-yellow, becoming greenish-yellow or darker from the maturing spores, mouths circular to angular, regular, rather small, edges entire; spores oblong-fusiform, greenish-brown when fresh, soon changing to ochraceous-brown, I2-I $5 \times 4-5 \mu$; stipe central, cylindric, equal or slightly tapering upward, light-yellow without and within, sometimes tinged with red near the middle or lower down, striate but not reticulate, ornamented with small, pallid, scurfy particles, which sometimes partially disappear with age, 5-7 $\mathrm{cm}$. long, 8-I $5 \mathrm{~mm}$. thick.

Rather common in woods from Nova Scotia to New York and westward to the Mississippi River.

\section{Ceriomyces scabripes (Peck) Murrill}

Pileus thick, firm, broadly convex, about $15 \mathrm{~cm}$. broad; surface dry, glabrous, reddish-brown with a bloom; context mild, though not pleasant to the taste; hymenium convex; tubes adnate or slightly depressed, brown within, mouths minute, circular, somewhat darker, becoming black on drying and exuding a black juice with a strong odor; spores oblong-ellipsoid or fusiform, smooth, yellowish-brown, II-I $4 \times 4-5 \mu$; stipe stout, equal, grayish-white, adorned with numerous small, projecting, black points, solid, but spongy within, about $10 \mathrm{~cm}$. long and $2-3 \mathrm{~cm}$. thick.

Found only at Bar Harbor, Maine, on rich soil in woods.

\section{Ceriomyces Roxanae (Frost) Murrill}

Pileus nearly plane, thin, circular, $3^{-7} \mathrm{~cm}$. broad; surface yellowish-brown, rarely yellow, clothed with minute, floccose tufts appearing under a lens as numerous fine warts, which partially disappear with age; margin regular, concolorous, often curving or rolling upward on drying; context thin, white, tinged with yellow; tubes at first adnate, at length depressed, white when young, becoming pale-yellow, mouths small, regular, angular, edges thin, entire; spores oblong-ellipsoid, Io $X+\mu$; stipe central, cylindric, tapering upward, bulbous at times at the base, yellow or ycllowish-brown, striate at the apex, variable in size, 4-7 cm. long, 5-15 mm. thick.

Occasional in borders of woods in Maine, Vermont, and New York. 


\section{Ceriomyces subtomentosus (L.) Murrill}

Pileus convex to expanded, 4-Io $\mathrm{cm}$. broad; surface dry, tomentose, often rimose-areolate, yellowish-brown, reddishbrown or subolivaceous; margin entire, often involute when young; context white or yellowish, unchanging, yellow beneath the cuticle, taste mild; tubes adnate or slightly depressed, often becoming nearly free, yellow, unchanging when wounded, greenish-yellow at the maturity of the spores, mouths large, irregular, sometimes compound, usually angular; spores greenish when fresh, fading to yellowish-brown, subfusiform, smooth, I0-I $2 \times 4-5 \mu$; stipe ventricose or nearly equal, tapering below, furfuraceous to glabrous, even or wholly or partially reticulate, pale-yellow or slightly brownish, often flavous above, reddishbrown when bruised, solid, white or yellowish within, $4.6 \mathrm{~cm}$. long, $0.5^{-1.5} \mathrm{~cm}$. thick.

Very common in deciduous woods throughout temperate North America. Edible.

\section{Ceriomyces tomentipes (Earle) Murrill}

Pileus thick, convex to expanded, 9-I $3 \mathrm{~cm}$. broad, about $3 \mathrm{~cm}$. thick; surface dry, minutely tomentose to glabrous, umbrinous; context whitish or discolored, changing to blue when wounded; hymenium ventricose, deeply and broadly sinuate-depressed, decurrent; tubes sordid-yellow, becoming brick-red when wounded or on drying, mouths small, about I mm. broad, circular; spores ellipsoid, brownish, about $14 \times 7 \mu$; stipe cylindric, densely but minutely velvety-pubescent, sometimes becoming nearly glabrous above, brick-red, flecked with brown below, solid, $8-\mathrm{I} 3 \mathrm{~cm}$. long, $2.5-3.5 \mathrm{~cm}$. thick.

Found only at Stanford University, California, among decaying oak leaves.

\section{Ceriomyces fumosipes (Peck) Murrill}

Pileus convex, $4-7 \mathrm{~cm}$. broad, about I-I.5 cm. thick; surface tomentose, avellaneous with light-bay spots to umbrinous or dark-olive-brown, very distinctly reticulate-rimose, the cracks becoming wider and whitish in color in older plants, while the areoles between contract almost into tufts, especially toward the margin, which is entire, fertile; context firm, fleshy, white, changing slowly and slightly to pale-blue, taste sweet; tubes plane in mass, somewhat depressed at maturity, equaling the thickness of the context, greenish-white to avellaneous; spores ellipsoid, smooth, deep-ochraceous-brown, I4-16 $\times 7-8 \mu$; stipe some- 
what ventricose, solid, white within, changing slightly to bluish beneath the cuticle, $3-4 \mathrm{~cm}$. long, $0.7-\mathrm{I} \mathrm{cm}$. thick, finely scabrous or scurfy, avellaneous-umbrinous to fulvous, paler above, distinctly pale-bluish-green at the apex.

Frequent in woods, especially on roadside banks, from New York to the mountains of North Carolina and west to Kentucky. It is readily recognized by the pale-bluish-green band at the apex of the stipe.

\section{Ceriomyces sordidus (Frost) Murrill}

Pileus convex to nearly plane, about $5 \mathrm{~cm}$. broad; surface dry, subtomentose, dirty-dark-brown, margin entire; context white, slightly tinged with green; tubes rather long, nearly free, at first white, changing to bluish-green; spores ovoid to ellipsoid, smooth, yellowish-brown, IO-I $2 \times 5^{-6 \mu}$; stipe equal or slightly smaller at the apex, brownish marked with darker streaks, usually greenish above, $5^{-7} \mathrm{~cm}$. long, I-I.5 cm. thick.

Found at Brattleboro, Vermont, growing in recent excavations in woods.

\section{Ceriomyces Communis (Bull.) Murrill}

Pileus convex to expanded, depressed at times with age, gregarious, $4-8 \mathrm{~cm}$. broad, I-2 $\mathrm{cm}$. thick; surface dry, tomentose to floccose-squamulose, often rimose-areolate, variable in color, usually some shade of red or purple, fading to brown (very frequently attacked by a whitish mold); margin entire, fertile; context yellowish-white to flavous, reddish beneath the cuticle, usually changing slowly to greenish or bluish when wounded, especially near the tubes, taste mild; tubes adnate, convex in mass, slightly decurrent, becoming much depressed at times with age, yellow or greenish-yellow, changing to greenish-blue when wounded, mouths large, angular, irregular, $\mathrm{I}-2$ to a $\mathrm{mm}$.; spores fusiform, smooth, olivaceous when fresh, fading to pale-brownish, I I-I $3 \times 4-5 \mu$; stipe subcylindric, often contorted, tapering at the base, flavous above, red or streaked with red below, longitudinally furrowed, glabrous or minutely scurfy, solid, sometimes yellow within at the base, $3^{-8 \mathrm{~cm}}$. long, $0.3^{-1.5} \mathrm{~cm}$. thick.

Extremely common in woods and on mossy banks at the edges of woods throughout temperate North America, and found also in the Bahamas. Edible, but somewhat mucilaginous.

\section{SUILLELLUS Murrill}

Hymenophore annual, terrestrial, centrally stipitate; surface glabrous or nearly so, dry or slightly viscid; context white or 
yellow, fleshy, considered poisonous in some species; tubes small, yellowish within, mouths red or orange from the first, not covered with a veil; spores oblong-ellipsoid, smooth, yellowish-brown, sometimes with greenish tints; stipe solid, usually reticulate or dotted.

Pileus yellow, brown, or red.

Stipe $2 \mathrm{~cm}$. or less in thickness.

Stipe yellow above and red below.

I. S. luridus.

Stipe red the entire length, or rarely yellow at the base.

Stipe reticulate.

Stipe not reticulate.

2. S. Frostii.

3. S. rubinellus.

Stipe over $5 \mathrm{~cm}$. thick.

4. S. Eastwoodiae.

Pileus olivaceous.

5. S. Morrisii.

\section{Suillellus LuRIDUS (Schaeff.) Murrill}

Pileus convex, gregarious or subcespitose, $5^{-12} \mathrm{~cm}$. broad; surface dry, smooth, glabrous or minutely tomentose, sometimes clothed with rather conspicuous appressed, felted fibers, occasionally rimose-areolate, brown with shades of red or yellow, often bright-brownish-red, becoming paler with age; margin thick, obtuse, entire, sometimes slightly differing in color; context firm, whitish to flavous, quickly changing to blue when wounded, sometimes unchanging in older plants, somewhat poisonous; tubes nearly free, rarely adnate, plane or slightly convex in mass, yellow within, changing to dark-greenish-blue when wounded, mouths small, circuiar, cinnabar-red, becoming brownish-orange, darker with age; spores oblong-ellipsoid, smooth, olivaceous when fresh, I I-I $6 \times 4-6 \mu$; stipe subequal, $5^{-10} \mathrm{~cm}$. long, $\mathrm{I}-2 \mathrm{~cm}$. thick, usually furfuraceous or punctate, at times nearly glabrous, rarely reticulate at the apex or on the upper half, red or reddish-brown below, yellow or orange above, the dots rosy or dark-red, solid, yeliow within, varied with red or purple.

Extremely common in open woods and on shaded banks throughout temperate North America. Somewhat poisonous.

\section{SuILlellus Frostir (Russell) Murrill}

Pileus convex to plane, gregarious, $6-15 \mathrm{~cm}$. broad; surface glabrous, shining, viscid in damp weather or when young, blood-red, sometimes paler-red with patches of yellow; context firm, juicy, white or yellowish, scarcely changing to grcenishblue when wounded, taste mild; tubes adnate, subdecurrent, depressed, straw-yellow within, changing slowly to greenish-blue when injured, yellowish-brown with age, mouths large, stuffed, 
edges blood-red; spores oblong-ellipsoid, smooth, brownishyellow, with a greenish tint when fresh, 12-I $5 \times 4-5 \mu$; stipe subventricose, tapering upward, blood-red, sometimes with yellow stains, becoming bluish-green when handled, deeply and beautifully alveolate-reticulate its entire length, solid, firm, yellowish within, 7-10 $\times 2 \mathrm{~cm}$.

Occasional in oak woods from New England to Virginia and west to Indiana and Tennessee. A very handsome species.

\section{Suillellus Rubinellus (Peck) Murrill}

Pileus convex or subconic to plane, often umbilicate, gregarious, $1.5-5 \mathrm{~cm}$. broad; surface reddish-brown, fading to yellow on the margin with age, slightly pubescent, somewhat viscid when moist; margin often recurved, thin, somewhat undulate; context white or pinkish, becoming yellowish when bruised, taste mild; tubes adnate or slightly depressed, $5 \mathrm{~mm}$. long, mouths at first reddish but soon turning brown, not changing color when bruised, small, circular or somewhat angular; spores oblong-fusiform, ferruginous-brown, Io-I $4 \times 3-4 \mu$; stipe equal, slender, even, pinkish-red changing to brown, solid, pale-yellow within, deeper yellow toward the base, often yellow externally at the base, I-4 cm. long, $2.5-7.5 \mathrm{~mm}$. thick.

Occasional in coniferous or mixed woods from New York to North Carolina and Kentucky. Glatfelter reported it as the most abundant bolete in Missouri.

\section{Suillellus Eastwoodiae Murrill}

Pileus thick, compact, hemispheric, solitary, nearly ro $\mathrm{cm}$. broad; surface smooth, glabrous, shining, not at all viscid, very light brown; margin entire, slightly projecting, concolorous; context firm, nearly white with a yellowish tint, changing to blue when wounded and later returning to its original color; tubes adnate, separating with age, about I $\mathrm{cm}$. long, concave to plane in mass, yellowish, mouths small, angular, pink; spores oblong-ellipsoid, smooth, pale-yellowish-brown under a micro ${ }^{3}$ scope from dried specimens, I I-I2.5 $\times 4-5 \mu$; stipe very much swollen at the center, contracted at the apex and base, even or reticulate, glabrous, concolorous with a rosy tint in certain parts, yellowish at the base, solid, yellowish-white within, $9 \mathrm{~cm}$. long, $7 \mathrm{~cm}$. thick at the center.

Known only from a few collections in the vicinity of San Francisco, California. 


\section{Suillellus Morrisin (Peck) Murrill}

Pileus convex, gregarious or at times subcespitose, $3-8 \mathrm{~cm}$. broad, I-2 cm. thick; surface dry, finely pulverulent, darkflavovirens to light-olivaceous, becoming partially or wholly glabrous and dull-reddish-brown; margin thin, inflexed, projecting beyond the tubes, often radially cracked; context flavous, unchanging, rather thin, sweet; tubes long, flavous to melleous or greenish-yellow, much depressed near the stipe, mouths subcircular, the extreme edges usually distinctly orange or testaceous; spores oblong-fusiform, smooth, yellowish-green, I2-I4 $\times 4-5 \mu$; stipe subfusiform, flavous, distinctly punctate with reddish dots nearly to the apex, solid, yellow or dark-purplish within, 4-8 cm. long, 8-12 mm. thick.

Occasional in deciduous or mixed woods in Massachusetts, New Jersey, Ohio, and Kentucky.

\section{ROSTKOVITES P. Karst.}

Hymenophore annual,'terrestrial, stipitate; surface viscid, glabrous or hirtellous; context fleshy, yellowish; tubes adnate, angular, yellow, not covered with a veil, exuding viscid drops which blacken on drying; spores oblong-ellipsoid, smooth, yellowish-brown; stipe solid, glandular-dotted, exannulate, not reticulate.

Pileus glabrous or nearly so.

Pileus brown when moist, yellowish on drying; stipe over 8 $\mathrm{mm}$. in diameter.

I. $R$. granulatus.

Pileus yellow, often streaked with bright-red; stipe usually slender, $8 \mathrm{~mm}$. or less in diameter.

2. $R$. subaureus.

Pileus adorned with conspicuous tufts of hairs.

3. $R$. hirtellus.

\section{Rostkovites granulatus (L.) P. Karst.}

Pileus subhemispheric to nearly plane, gregarious, rarely cespitose or solitary, $4-I 0 \mathrm{~cm}$. broad, I-I.5 cm. thick; surface very viscid, with easily separable cuticle, very variable in color, usually pinkish-gray to reddish-brown fading to yellowish, often obscurely spotted, especially at the center; margin sterile, projecting, incurved and somewhat appendiculate when young; context thick, compact, elastic, pale-yellow next to the tubes, white above, unchanging when wounded, taste mild, somewhat mucilaginous; tubes short, less than $5 \mathrm{~mm}$., adnate, subdecurrent, plane in mass, pale-yellow to dirty-yellowish, unchanging when wounded, mouths simple, subcircular, irregular, edges rather thick, flecked with pinkish-brown glandules; spores fusiform, 
pale-yellowish-brown, $7.5-9.5 \times 2.5-3.5 \mu$; stipe short, thick, subequal or enlarged below, white or pale-yellow, dotted with pinkish-brown droplets which become darker on drying, solid, white within, $2.5-5 \mathrm{~cm}$. long, $\mathrm{I}-\mathrm{I} .5 \mathrm{~cm}$. thick. ?

Extremely common in open woods, especially near conifers, throughout temperate North America and also found at high elevations in the Blue Mountains, Jamaica. Edible.

\section{Rostkovites subaureus (Peck) Murrill}

Pileus thin, convex to expanded, sometimes umbonate, 5-Io $\mathrm{cm}$. broad; surface very viscid, yellow, often dotted or streaked with bright-red, dingy with age, sometimes spotted from the drying of the gluten; margin slightly tomentose or appendiculate when young; context comparatively thick, fleshy-tough, paleyellow, pinkish-gray when wounded, taste mild; tubes adnate, scarcely decurrent, plane in mass, bright-yellow to dull-ochraceous, flecked with yellowish, exuding drops which blacken with age, mouths rather large, angular, edges obtuse; spores oblong-ellipsoid, smooth, ochraceous-ferruginous, 8.5-I I $\times 4^{-5} \mu$; stipe slender, tapering upward, yellow, darker toward the base, covered with numerous brownish or reddish-brown glandular dots which blacken with age, solid, yellow within, $4-7 \mathrm{~cm}$. long, 4-8 mm. thick.

Common in woods and wood borders, especially near conifers, throughout eastern North America. Edible.

\section{Rostkovites hirtellus (Peck) Murrill}

Pileus broadly convex, subcespitose, $5^{-10} \mathrm{~cm}$. broad; surface soft, viscid, golden-yellow, adorned with small tufts of hairs or fibrils; context pale-yellow; tubes adnate, of medium size, becoming dingy-ochraceous, mouths angular; spores paleochraceous-brown, 9-10 $\times 4 \mu$; stipe stout, equal, glandulardotted, yellow, 4-7 cm. long, $0.8-1.2 \mathrm{~cm}$. thick.

Occasional in sandy soil under pines in Connecticut and New York.

\section{BOLETUS (Dill.) L.}

Hymenophore annual, terrestrial, centrally stipitate; surface viscid, glabrous or scaly; context fleshy, white or yellowish; tubes adnate, small, angular, yellowish, covered with a whitish veil; spores oblong-ellipsoid or rarely globose, smooth, yellowish-brown; stipe solid, annulate, often glandular-dotted.

\section{Surface glabrous.}

Stipe glandular-dotted.

Stipe not at all reticulate. x. B. luteus. 
Stipe reticulate above the annulus.

Stipe not glandular-dotted.

Spores globose or subglobose.

Spores oblong-ellipsoid.

Surface floccose-scaly.
2. B. amabilis.

3. B. sphaerosporus.

4. B. Clintonianus.

5. B. Lakei.

\section{Boletus luteus L.}

Pileus convex, solitary, 5-Io $\mathrm{cm}$. broad; surface smooth, glabrous, very viscid, yellowish-brown, grayish-brown, or reddish-brown, sometimes streaked, becoming darker and duller with age; margin thin, entire or undulate; context compact, pale-yellowish, darker with age, unchanging when wounded, edible; tubes $\mathrm{I} .5^{-2.5} \mathrm{~mm}$. long, plane or convex in mass, adnate or slightly decurrent, somewhat depressed, dark-melleous, unchanging when wounded, darker with age, mouths $\mathrm{I} \mathrm{mm}$. in diameter, nearly circular, edges adorned with reddish-brown dots; spores oblong-fusiform, smooth, yellowish-brown, 6-9 $\times 2.5-4 \mu$; stipe slightly tapering downward, pale-yellow to reddish-brown, glandular-dotted both above and below the annulus, solid, yellowish and unchanging within, about $3-6 \mathrm{~cm}$. long, I-2 cm. thick; annulus large, membranous, white to slightly brownish, glandular-dotted, persistent.

Common in sandy soil in coniferous or mixed woods throughout the eastern United States. Edible.

\section{Boletus amabilis Peck}

Pileus circular, convex, $5^{-1} 8 \mathrm{~cm}$. in diameter; surface glabrous, reddish-tawny, with small brown or blackish-brown spots in dried specimens, probably viscid when fresh; margin even, sterile, concolorous; context pallid; tubes decurrent to the annulus, short, yellow, mouths angular, radially elongate, edges thin, entire; stipe equal or slightly tapering downward, paler than the pileus, reticulate above the small whitish annulus, solid, $2.5-5 \mathrm{~cm}$. long, 8-16 mm. thick.

Collected a few times in dense spruce woods in Colorado.

\section{Boletus sphaerosporus Peck}

Pileus circular, convex, $7-15 \mathrm{~cm}$. broad; surface smooth, glabrous, viscid, cream-colored when young, becoming reddishbrown with age; margin thin, even, regular, sterile, often inflexed when dry, ornamented with portions of the veil; context palcyellowish, becoming brownish with age; tubes adnate or somewhat decurrent, pale-yellow or yellowish-buff, becoming olivebrown or brown with age, tinged with green at times, mouths 
large, angular, uneven, shallow near the margin, edges thin, some of them elongated into coarse teeth; spores globose or broadly ellipsoid, $7.5^{-9} \mu$ long; stipe thick, equal, 3-7 cm. long, I.5-3 cm. thick, reticulate at the apex only, or for half the distance downward, bearing near the base a very conspicuous, white, membranous, sheathing, persistent annulus.

Frequent in low ravines and sandy places in woods in Wisconsin, Iowa, and Minnesota.

\section{Boletus Clintonianus Peck}

Pileus convex, gregarious, 5-12 $\mathrm{cm}$. broad; surface goldenyellow to chestnut, becoming darker with age, smooth, viscid, glabrous, with separable cuticle; margin at first incurved, then thin and spreading; context $5 \mathrm{~mm}$. or more thick, soft, paleyellow or golden-yellow, becoming very slightly greenish when wounded, taste mild; tubes $5^{-7} \mathrm{~mm}$. long, nearly plane in mass, adnate or subdecurrent, not depressed, pale-yellow to melleous, slightly discolored within when wounded, mouths subcircular, more or less compound, small, rather irregular, edges acute, changing to reddish or purplish-brown when bruised; spores oblong, brownish-ochraceous, IO-I $2 \times 4^{-5} \mu$; stipe subequal, straw-yellow and slightly reticulate at the apex, reddish-chestnut and even below, solid, straw-yellow within, becoming slightly reddish when bruised, $5^{-1} 2 \mathrm{~cm}$. long, I-2 cm. thick; annulus cottony-white or yellowish, ample, persistent, often appearing double.

Occasional in shaded grassy places in Canada and the northcastern United States south to New Jersey and west to Wisconsin.

\section{Boletus Lakei Murrill}

Pileus convex, often becoming plane, gregarious or subcespitose, rarely solitary, $8-12 \mathrm{~cm}$. broad; surface fulvous with latericeous tints, appearing testaceous, densely imbricatefloccose-scaly, owing to the rupture of the cuticle; margin white, sterile, entire, involute when young; context sulphur-yellow, unchanging or turning slightly yellowish-green when cut, with pleasant odor and mild flavor; tubes large, decurrent, elongate near the stipe, flavous when young, dark-dirty-flavous with a greenish tint when older, unchanging when bruised; spores oblong-ellipsoid, smooth, yellowish-brown, $8.5-10.5 \times 3.5 \mu$; stipe subequal, $7 \times 2 \mathrm{~cm}$., flavous at the apex, then testaceous, then adorned with the ample, white, persistent, cottony annulus, and below this similar to the pileus in color and surface markings. 
This species is similar to $B$. luteus and takes its place in the flora of the Pacific Coast; but the tubes are larger and the surface is floccose-scaly. At Corvallis, Oregon, it is very abundant in fir woods mixed with a few deciduous trees. It is also known from Washington and California.

\section{BOLETELLUS Murrill}

Hymenophore annual, epixylous, centrally stipitate; surface floccose-verrucose, yellowish; context light-colored, fleshy; tubes angular, depressed, yellowish, covered with a veil; spores oblongellipsoid, smooth, ferruginous; stipe solid, white, not reticulate.

\section{Boletellus Ananas (M. A. Curt.) Murrill}

Pileus convex to expanded, somewhat irregular, $5^{-10} \mathrm{~cm}$. broad; surface light-tan with a pinkish tint to pinkish-brown, covered with a thick coat of conspicuous, imbricate, floccose scales, which are reddish-flesh-colored fading to almost white; margin thin, lacerate, appendiculate; context white or creamcolored, changing to bluish when wounded; tubes plane in mass, adnexed, bright-yellow or tawny-yellow, sometimes with a pinkish tint, becoming greenish-blue when injured, mouths of medium size, angular, edges thin; spores ellipsoid, longitudinally striate, dark-brown, I6-I $8 \times 6-8 \mu$; stipe 5-10 cm. long, $\mathrm{I}-2 \mathrm{~cm}$. thick, cylindric, even, pure-white or very light brownish, sometimes tinged with pink, changing to dull-red when wounded, solid or slightly hollow within; veil present in young stages, but mostly clinging to the margin of the pileus, leaving only a slight trace of an annulus in mature specimens.

Frequent from North Carolina to Alabama and Mississippi, growing parasitically on wounded pine trunks or about the base of living pine trees.

\section{PULVEROBOLETUS Murrill}

Hymenophore annual, terrestrial, centrally stipitate; surface of pileus and stipe clothed with a conspicuous sulphur-yellow, powdery tomentum, which may be the remains of a universal veil; context white, fleshy; tubes adnate, yellowish, covered with a large veil; spores oblong-ellipsoid, ochraccous-brown; stipe solid, annulate, not reticulate.

\section{Pulveroboletus Ravenelin (Berk. \& Curt.) Murrill}

Pileus convex or nearly plane, $3-10 \mathrm{~cm}$. broad, $\mathrm{I}-3 \mathrm{~cm}$. thick; surface smooth, slightly viscid when wet, subfibrillose and 
pulverulent, becoming glabrous on the disk, isabelline to testaceous or latericeous, the pulverulence being sulphur-yellow, margin entire, flavous; context white or very light yellow, changing slowly to bluish when wounded; tubes plane in mass, adnate, depressed, pale-yellow to umbrinous-olivaceous, changing to greenish-blue when injured, mouths of medium size, subcircular or slightly sinuate; spores ellipsoid, olive-green when fresh, becoming ochraceous-brown, 10-12 $\times 5^{-6} \mu$; stipe cylindric, equal, clothed and colored like the young pileus, solid, yellow within, not changing to blue when wounded, $5^{-10} \mathrm{~cm}$. long, $0.5^{-1.3} \mathrm{~cm}$. thick; veil large and conspicuous, bright-lemonyellow, remaining attached to the stipe in the form of a slight, evanescent, tomentose annulus.

Occasional in the eastern United States from New England to the Gulf of Mexico, preferring deep shade and often found in thickets of Kalmia and Rhododendron.

\section{STROBILOMYCES Berk.}

Hymenophore annual, terrestrial, centrally stipitate; surface of pileus and stipe blackish and shaggy; context white, at first fleshy, becoming tough; tubes angular, adnate, white when young, covered with a floccose veil; spores globose or broadly ellipsoid, rugulose, blackish-brown; stipe solid, not reticulate.

\section{Strobilomyces strobilaceus (Scop.) Berk.}

Pileus hemispheric to expanded, 5-10 $\mathrm{cm}$. broad; surface dry, soft and spongy, blackish-umbrinous, adorned with thick, projecting, floccose, squarrose, blackish scales; margin fringed with scales and fragments of the veil; context white or whitish, changing to red and then to black when wounded, mild to the taste, edible; tubes adnate, often depressed, white or cinereous, changing like the context when wounded, becoming brown or blackish with age, mouths large, angular; spores subglobose, asperulate, blackish-brown, 8-1 I $\mu$ long; stipe equal or slightly tapering upward, sulcate-striate at the apex, densely floccosetomentose, brown or blackish below, lighter above, solid, firm, fragile, 6-12 cm. long, I-2 cm. thick; veil dense, cottony, white to grayish, adhering to the margin and to the stipe in mature plants.

Very common on shaded banks in woods throughout temperate North America. Edible. 


\section{Io. BOLETINELLUS Murrill}

Hymenophore annual, terrestrial or sometimes attached to buried roots; pileus circular, varying to dimidiate at times; surface dry, minutely tomentose to floccose-tomentose; context white or yellowish, fleshy; tubes decurrent, large, shallow, elongate, not easily separating, radiating, yellow, not covered with a veil; spores ellipsoid, smooth, some shade of brown; stipe central, eccentric or lateral, solid, fleshy, or spongy.

Stipe eccentric or lateral; pileus reddish-brown, glabrous or minutely tomentose.

I. B. merulioides.

Stipe central.

Pileus dark-chestnut, subtomentose.

Pileus bright-red, floccose-tomentose.

2. B. castanellus.

3. B. paluster.

\section{honesece}

\section{Boletinellus merulioides (Schw.) Murrill}

Pileus thin, irregular, usually lobed, more or less deeply depressed at maturity, gregarious, 5-12 cm. broad; surface dry, minutely tomentose, dull-reddish-brown, margin undulate or deeply lobed; context 5-10 $\mathrm{mm}$. thick, yellow, changing slowly to bluish-green when wounded, having a musty or unpleasant odor; tubes decurrent, hymenium honey-yellow when young, becoming dull-yellow with age, often changing slightly to blue when wounded, tubes formed by radiating lamellae $2-3 \mathrm{~mm}$. apart, branching and connected by numerous irregular veins of less prominence; spores subovoid to ellipsoid, smooth, yellow to brownish-ochraceous, 8-I I $\times 5-7 \mu$; stipe lateral or eccentric, tough, expanded into the pileus, reticulate at the apex by the decurrent walls of the tubes, concolorous, clothed like the pileus, hollow, I-3 cm. long, 8-12 mm. thick.

Common from Canada to Alabama and west to Wisconsin, on shaded banks and in low places in woods.

\section{Boletinellus castanellus (Peck) Murrill}

Pileus convex or nearly plane, $2.5-4 \mathrm{~cm}$. broad; surface dry, subtomentose, soft, spongy, dark-chestnut; context white or yellowish-white; tubes adnate or slightly decurrent, nearly plane in mass, brown, mouths large, angular; spores ellipsoid, 7.5-10 $\times 5 \mu$; stipe short, concolorous, glabrous, slightly reticulate at the apex, solid, whitish or grayish within, $2.5 \mathrm{~cm}$. long, 4-8 mm. thick.

Occasional in woods from New York to Virginia. 


\section{Boletinellus Paluster (Peck) Murrill}

Pileus thin, broad, convex to plane or slightly depressed, at times with a small umbo, $3-7 \mathrm{~cm}$. broad, $1.5^{-2} \mathrm{~cm}$. thick; surface floccose-tomentose, bright-red; margin thin, subincurved; context yellowish-white, unchangeable, comparatively thick; tubes slightly decurrent, short, yellow, changing to bluish-green when wounded, becoming sordid-ochraceous with age, mouths very large, $\mathbf{I}-2 \mathrm{~mm}$. in radial diameter, compound, angular; spores ellipsoid, dirty-greenish-yellow when fresh, becoming pinkishbrown, $6-8 \times 2.5-4 \mu$; stipe slender, yellow and striate at the apex, minutely squamulose, strongly tinged with red, yellow and tomentose at the base, solid, $2.5-5 \mathrm{~cm}$. long, 4-6 mm. thick.

Occasional in wet and mossy places from Ontario to New Jersey and west to Wisconsin.

\section{BOLETINUS Kalchb.}

Hymenophore annual, terrestrial or rarely epixylous, centrally stipitate; surface dry, minutely silky to fibrillose or squamose; context whitish or yellowish, fleshy or spongy; tubes large, shallow, elongate, tough, not easily separating, radiately arranged, adnate or slightly decurrent, yellowish, covered with a veil; spores elongate, smooth, yellowish-brown to purplish-brown, sometimes with greenish tints; stipe more or less annulate, spongy or hollow within.

Stipe hollow; pileus tawny-brown, fibrillose-squamulose.

Stipe solid.

Pileus whitish or grayish, slightly squamulose.

Pileus yellow or yellowish.

Pileus $9 \mathrm{~cm}$. or less broad.

Pileus $10 \mathrm{~cm}$. or more broad.

Pileus red or reddish, conspicuously squamose.

Spores purplish-brown; scales scattered.

Spores ochraceous-brown; scales dense.
I. B. cavipes.

2. B. grisellus.

3. B. Berkeleyi.

4. B. appendiculatus.

5. B. spectabilis.

6. B. pictus.

\section{Boletinus cavipes (Opat.) Kalchb.}

Pileus broadly convex, rather tough, flexible, usually subumbonate, 3.5-10 cm. broad; surface soft, fibrillose-squamulose, tawny-brown, sometimes tinged with reddish or purplish; context thin, yellowish; tubes slightly decurrent, pale-yellow when young, darker and tinged with green at maturity, becoming dingy-ochraceous with age; spores ellipsoid, olivaceous when fresh, changing later to yellowish-ochraceous, $7 \cdot 5^{-10} X+\mu$; stipe equal or slightly tapering upward, slightly fibrillose or 
floccose, tawny-brown or yellowish-brown, yellowish at the apex, hollow within, sometimes stuffed when young, $3 \cdot 5-7 \mathrm{~cm}$. long, 6-12 $\mathrm{mm}$. thick; veil white, evanescent, partly adhering to the margin of the pileus and partly to the stipe in the form of a delicate annulus.

Occasional in swampy or mossy places in New England and New York.

\section{Boletinus GRISEllus Peck}

Pileus convex to nearly plane, $3^{-7} \mathrm{~cm}$. broad; surface dry, slightly fibrillose-squamulose, whitish or grayish, sometimes tinged with yellow; context white, unchanging; tubes adnate or slightly decurrent, grayish, becoming brownish with age, mouths rather large and angular; spores oblong or ellipsoid, ferruginousbrown, $7 \cdot 5-10 \times 4-5 \mu$; stipe equal or slightly tapering upward, whitish or pallid, slightly reticulate at the apex by the decurrent walls of the tubes, $2.5^{-5} \mathrm{~cm}$. long, $0.5^{-1} \mathrm{~cm}$. thick; veil in young plants slight, webby or fibrillose, soon disappearing.

Found under or near larch trees at Natick, Massachusetts.

\section{Boletinus Berkeleyi Murrill}

Pileus convex above, nearly plane below, becoming somewhat irregular on expanding, $7-9 \mathrm{~cm}$. broad, about $3 \mathrm{~cm}$. thick at the center; surface dry, minutely silky, slightly scaly on the disk, whitish-yellow or dirty-yellowish-brown, sometimes faintly speckled; margin acute, entire, appendiculate; context yellow, taste mild; tubes scarcely decurrent, adnate, plane or somewhat concave in mass, yellow, becoming brownish-yellow with age; spores rather small, oblong, ochraceous-ferruginous, $8-10 \times$ $3^{-4} \mu$; stipe equal, usually curved, tapering below, brownishyellow, subfloccose to glabrous, solid or spongy and yellow within, $5^{-8} \mathrm{~cm}$. long, $0.7-1.5 \mathrm{~cm}$. thick; veil floccose, evanescent, adhering partly to the margin and partly to the summit of the stipe in the form of a slight annulus.

Occasional in thin woods from New Jersey to Florida and west to Kentucky.

\section{Boletinus appendiculatus Peck}

Pileus convex, IO-20 cm. broad; surface glabrous, ochraceousyellow; margin appendiculate, with a thin, incurved, conspicuous veil; context pale-yellow, unchanging; tubes yellow, becoming darker or brownish when wounded, mouths rather small, angular, unequal; spores oblong-ellipsoid, pale-yellow, IO-I2 $\times 4 \mu$; stipe slightly thickened at the base, yellow, solid, 5-7 cm. long, 8-12 mm. thick.

Found under fir trees in the state of Washington. 


\section{Boletinus spectabilis Peck}

Pileus broad, convex, 5-10 $\mathrm{cm}$. broad; surface bright-red, viscid when moist, at first covered with a red tomentum, becoming squamose and fading to grayish-red or yellowish-brown; context whitish or pale-yellow, becoming deeper yellow on exposure, emitting a strong, unpleasant odor; tubes adnate, convex in mass, ochraceous, concealed at first by a reddish, glutinous membrane, mouths large, angular; spores oblong-ellipsoid, pointed at one end, usually with one or two nuclei, cremeousmelleous or darker under a microscope, purplish-brown in mass, I2-I $4 \times 5 \mu$; stipe subequal, yellow above the annulus, red or yellowish-red below, 7-I2 cm. long, 8-I2 mm. thick; veil tomentose when young, remaining in the form of scales on the pileus and a ring on the stipe.

Occasional in exposed swamps from Canada to New York and west to Wisconsin.

\section{Boletinus pictus Peck}

Pileus convex to expanded, gregarious, $5-8 \mathrm{~cm}$. broad; surface dry or slightly viscid, imbricate-scaly, at first deep-red, later becoming fawn-colored owing to the separation of the dense, fibrillose tomentum into scales; margin often appendiculate; context thick, tough, creamy-yellow, changing slowly to pinkish when bruised, becoming yellowish-brown with age; tubes adnate, somewhat decurrent, not depressed, short, pale-yellow, sometimes changing to pinkish-brown when bruised, becoming dullyellowish-brown with age, mouths angular, large, compound; spores ellipsoid, smooth, stramineous under a microscope, ochraceous or pale-brown in mass; stipe cylindric, slightly tapering downward, yellowish above, subglabrous below, squamulose, solid or spongy within, sometimes becoming hollow, the flesh white with brownish discolorations toward the base, $5^{-7}$ $\mathrm{cm}$. long, I $\mathrm{cm}$. or less thick; veil white, thin, copious, tomentose, remaining in mature plants partly attached to the margin, but mostly on the stipe as a dense, tomentose covering and an irregular, subapical annulus.

Common in woods and mossy swamps in the mountainous regions of eastern North America. Very beautiful and edible. 


\section{INDEX TO GENERA WITH SPECIES}

Boletellus, 33

Ananas, 33

Boletinellus, 35

castanellus, 35

merulioides, 35

paluster, 36

Boletinus, 36

appendiculatus, 37

Berkeleyi, 37

cavipes, 36

grisellus, 37

pictus, 38

spectabilis, 38

Boletus, 30

amabilis, 3 I

Clintonianus, 32

Lakei, 32

luteus, $3 \mathrm{I}$

sphaerosporus, 31

Ceriomyces, 5

affinis, I4

alabamensis, 20

albellus, 9

Atkinsonianus, I6

auriflammeus, 13

auriporus, I2

Betula, 8

bicolor, 22

chromapes, Io

communis, 26

conicus, II

crassus, I4

Curtisii, 15

eximius, I3

ferruginatus, 15

flaviporus, 12

frustulosus, 9

fumosipes, 25

griseo-roseus, II

griseus, Io

guadalupensis, 2 I

hemichrysus, I3

Housei, 18

illudens, I9

inflexus, 16

jalapensis, 17
Ceriomyces, Maxoni, 2 I miniato-olivaceus, 2 I mirabilis, I9

oregonensis, 22

pallidus, 23

parasiticus, I3

Peckii, I 8

retipes, 20

Roxanae, 24

Russellii, 8

scabripes, 24

sordidus, 26

speciosus, I7

subglabripes, 23

subpallidus, 20

subsanguineus, 18

subtomentosus, 25

tabacinus, I 7

tomentipes, 25

Vanderbiltianus, II

viscidus, Io

Zelleri, 23

Gyroporus, I

castaneus, 2

cyanescens, 2

subalbellus, 3

Pulveroboletus, 33

Ravenelii, 33

Rostkovites, 29

granulatus, 29

hirtellus, 30

subaureus, 30

Strobilomyces, 34 strobilaceus, 34

Suillellus, 26

Eastwoodiae, 28

Frostii, 27

luridus, 27

Morrisii, 29

rubinellus, 28

Tylopilus, 3

alboater, 4

felleus, 3

gracilis, 4

indecisus, 4 


\section{INDEX TO SPECIES}

affinis (Ceriomyces), I4 alabamensis (Ceriomyces), 20 alboater (Tylopilus), 4 albellus (Ceriomyces), 9 amabilis (Boletus), 3 I Ananas (Boletellus), 33 appendiculatus (Boletinus), 37 Atkinsonianus (Ceriomyces), I6 auriflammeus (Ceriomyces), I3 auriporus (Ceriomyces), I2 Berkeleyi (Boletinus), 37 Betula (Ceriomyces), 8 bicolor (Ceriomyces), 22 castanellus (Boletinellus), 35 castaneus (Gyroporus), 2 cavipes (Boletinus), 36 chromapes (Ceriomyces), Io Clintonianus (Boletus), 32 communis (Ceriomyces), 26 conicus (Ceriomyces), i I crassus (Ceriomyces), I4 Curtisii (Ceriomyces), I5 cyanescens (Gyroporus), 2 Eastwoodiae (Suillellus), 28 eximius (Ceriomyces), I3 felleus (Tylopilus), 3 ferruginatus (Ceriomyces), I5 flaviporus (Ceriomyces), I2 Frostii (Suillellus), 27 frustulosus (Ceriomyces), 9 fumosipes (Ceriomyces), 25 gracilis (Tylopilus), 4 granulatus (Rostkovites), 29 grisellus (Boletinus), 37 griseo-roseus (Ceriomyces), I I griseus (Ceriomyces), ro guadalupensis (Ceriomyces), 2 I hemichrysus (Ceriomyces), I3 hirtellus (Rostkovites), 30 Housei (Ceriomyces), I 8 illudens (Ceriomyces), I9 indecisus (Tylopilus), 4 inflexus (Ceriomyces), I6 jalapensis (Ceriomyces), I7 Lakei (Boletus), 32 luridus (Suillellus), 27 luteus (Boletus), 3 I Maxoni (Ceriomyces), 2I merulioides (Boletinellus), 35 miniato-olivaceus (Ceriomyces), 2 I mirabilis (Ceriomyces), I9 Morrisii (Suillellus), 29 oregonensis (Ceriomyces), 22 pallidus (Ceriomyces), 23 paluster (Boletinellus), 36 parasiticus (Ceriomyces), I3 Peckii (Ceriomyces), I8 pictus (Boletinus), 38 Ravenelii (Pulveroboletus), 33 retipes (Ceriomyces), 20 Roxanae (Ceriomyces), 24 rubinellus (Suillellus), 28 Russellii (Ceriomyces), 8 scabripes (Ceriomyces), 24 sordidus (Ceriomyces), 26 speciosus (Ceriomyces), I7 spectabilis (Boletinus), 38 sphaerosporus (Boletus), 3 I strobilaceus (Strobilomyces), 34 subalbellus (Gyroporus), 3 subaureus (Rostkovites), 30 subglabripes (Ceriomyces), 23 subpallidus (Ceriomyces), 20 subsanguineus (Ceriomyces), 18 subtomentosus (Ceriomyces), 25 tabacinus (Ceriomyces), I7 tomentipes (Ceriomyces), 25 Vanderbiltianus (Ceriomyces), II viscidus (Ceriomyces), ro Zelleri (Ceriomyces), 23 


\section{Manuals of Polypores and Boletes}

By William A. Murrill, A.M., Ph.D., Assistant Director of the New York Botanical Garden, Editor of Mycologia, and Associate Editor of North American Flora.

Northern Polypores, issued in November, I9I4 . \$1.00

Including species found in Canada and the United States south to Virginia and west to the Rockies.

Southern Polypores, issued in January, I9I5 . . \$1.00

Including species found in the United States from North Carolina to Florida and west to Texas.

Western Polypores, issued in February, I915 . . \$I.00

Including species found in the states on the Pacific coast from California to Alaska.

Tropical Polypores, issued in March, I9I5 . . . \$1.50

Including species found in Mexico, Central America, southern Florida, the West Indies, and other islands between North America and South America.

American Boletes, issued in November, 19I4 . . \$1.00

Including all the species found in temperate and tropical North America, both on the mainland and on the islands, south to South America.

The above prices include prepaid postage, even to foreign countries. No reduction is made to any one, dealers included. The author regrets that, owing to the small editions, no copies can be distributed for examination, but a free desk copy will be supplied, if requested, with an order for ten copies of the same book sent to one address.

Remit by Postoffice or Express Money Order, or, if by Check, please add Exchange.

W. A. MURRILL

Bronxwood Park

NEW YORK CITY 





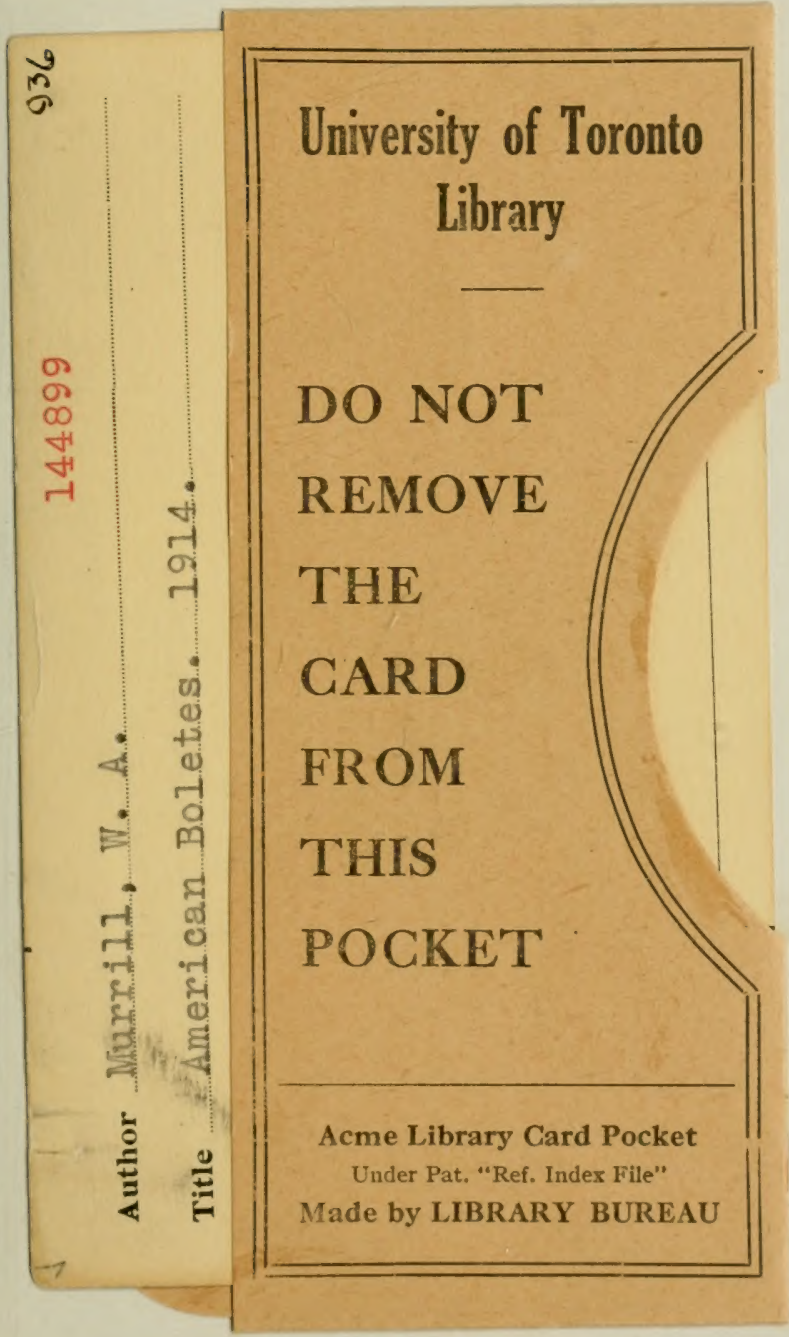




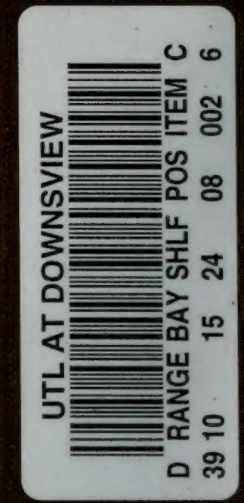

3 